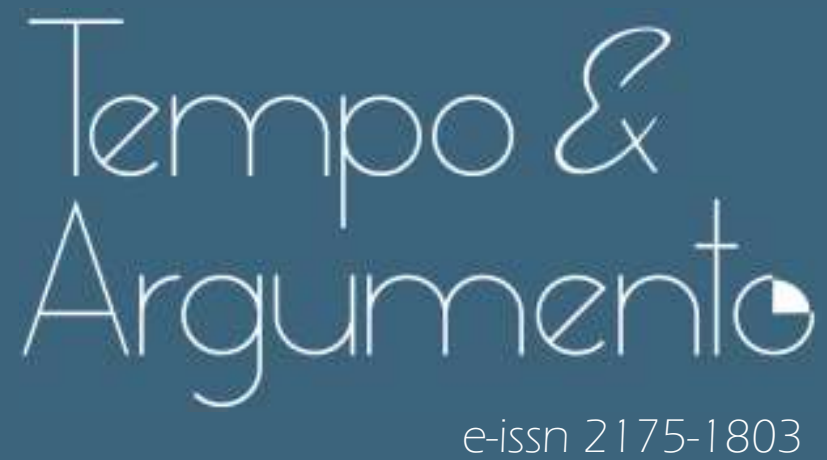

\title{
Ditadura militar brasileira nas aulas de História
}

- Verena Alberti

Doutora em Teoria da Literatura pela Universidade de Siegen (Alemanha).

Estágio Pós-Doutoral em Ensino de História pela Universidade de East Anglia

(Inglaterra) e pela Universidade de Londres (Inglaterra). Professora da Universidade do Estado do Rio de Janeiro (UERJ) e da Escola Alemã Corcovado, no Rio de Janeiro.

Rio de Janeiro, RJ - BRASIL

lattes.cnpq.br/0662658499050484

verenalberti@gmail.com

(D) orcid.org/0000-0003-2145-7870

Para citar este artigo:

ALBERTI, Verena. Ditadura militar brasileira nas aulas de História. Tempo e Argumento, Florianópolis, v. 13, n. 33, e0102, maio/ago. 2021.

dol http://dx.doi.org/10.5965/2175180313332021e0102

Recebido: 22/01/2021

Aprovado: 18/05/2021 


\title{
Ditadura militar brasileira nas aulas de História
}

\begin{abstract}
Resumo
Não é fácil trabalhar a ditadura militar brasileira nas aulas de História. Professores e professoras precisamos nos respaldar em documentos oficiais que legitimem o tratamento desse assunto e a Educação em Direitos Humanos. Além disso, precisamos saber o que gostaríamos que nossos alunos e nossas alunas aprendessem, tendo em vista ideias equivocadas hoje existentes acerca da ditadura e da transição para a democracia. Trazer as disputas de memória para dentro da sala de aula pode ser promissor. E, trabalhando com documentos, buscar compreender as ações das pessoas naquele período, enfatizando não "lições éticas", mas a compreensão da historicidade. Com isso, talvez possamos proporcionar um aprendizado efetivo, que permita um reordenamento de entendimentos, considerando a complexidade do passado e do presente.
\end{abstract}

Palavras-chave: Ensino de História; ditadura militar; disputas de memória; trabalho com documentos.

\section{Brazilian military dictatorship in History classes}

\begin{abstract}
It is not easy to address the Brazilian military dictatorship in History classes. Teachers need to rely on official documents legitimizing the approach to this theme and Education in Human Rights. Also, we need to know clearly what we would like our students to learn, given the mistaken ideas that exist today about the dictatorship and the transition to democracy. Bringing memory disputes into the classroom may be promising. And, working with documents, seek to understand people's actions during that period, not emphasizing 'ethical lessons,' but the understanding of historicity. Thus, perhaps we can perhaps provide effective learning, which allows for a re-ordering of knowings, considering the complexity of the past and present.
\end{abstract}

Keywords: History teaching. Military dictatorship. Memory disputes. Working with documents.

\section{Dictadura militar brasileña en las clases de Historia}

\section{Resumen}

No es fácil abordar la dictadura militar brasileña en las clases de Historia. Los y las docentes debemos apoyarnos en documentos oficiales que legitimen el enfoque de este tema y la Educación en Derechos Humanos. Además, necesitamos saber con claridad qué nos gustaría que aprendan nuestros alumnos y nuestras alumnas, dadas las ideas equivocadas que existen hoy sobre la dictadura y la transición a la democracia. Traer las disputas de memoria al aula puede ser prometedor. Y, trabajando con documentos, buscar comprender las acciones de las personas durante ese período, enfatizando no las "lecciones éticas", sino la comprensión de la historicidad. Por lo tanto, tal vez podamos brindar un aprendizaje efectivo, que permita reordenar los entendimientos, considerando la complejidad del pasado y del presente.

Palabras clave: Enseñanza de Historia. Dictadura militar. Disputas de memoria. Trabajo con documentos. 
"Pedras de tropeço", ou "obstáculos" (em alemão, Stolpersteine) - eis o nome que o artista plástico Gunter Demnig deu ao projeto iniciado em 2003 que consiste na instalação de pequenas placas de bronze nas calçadas em frente à última residência onde moravam vítimas do nacional-socialismo antes de serem perseguidas pelo regime. Hoje as "pedras de tropeço” já estão instaladas em 1.200 locais em 23 países da Europa. Nelas estão inscritos breves textos que começam com as palavras "Aqui morava..." ou "Aqui moravam...", seguindo-se os nomes das pessoas e informações relativas às datas em que foram deportadas, exiladas ou mortas $^{1}$. As crianças e os jovens que crescem nos lugares onde as placas estão instaladas têm o privilégio de "tropeçar" em registros sobre pessoas reais a caminho da escola ou de seus locais de lazer.

No Brasil, é possível que muitos jovens tenham, na memória, mais registros das violações cometidas pelo nazismo do que daquelas que foram cometidas pelo Estado durante nossa ditadura militar (1964-1985)2. Aqui, até o momento só temos 1 instituição de memória voltada ao período, o Memorial da Resistência de São Paulo, inaugurado nos anos 2000 nas instalações do antigo Departamento Estadual de Ordem Política e Social (DEOPS), local de encarceramento durante as duas ditaduras de nossa história republicana: o Estado Novo (1937-1945) e a ditadura militar ${ }^{3}$. O trabalho de memória, verdade e justiça que fizemos após o fim da ditadura se mostra tardio e modesto em comparação ao de outros países da América Latina. A Comissão Nacional da Verdade (CNV), aprovada por lei em novembro de 2011 e instalada em maio de 2012, publicou seu relatório em dezembro de 2014, passados mais de 50 anos do golpe militar de 31 de março

${ }^{1}$ Sobre o projeto, ver http://www.stolpersteine.eu/en/. Acesso em: 13 jul. 2020.

2 Em depoimento prestado em 2013, no seminário "Verdade e Infância Roubada: Crianças Atingidas pela Ditadura", realizado no âmbito da Comissão Estadual da Verdade de São Paulo, instalada por resolução da Assembleia Legislativa do Estado de São Paulo (Alesp) em fevereiro de 2012, Eliana Paiva, filha do deputado federal Rubens Paiva, morto pela ditadura em 1971, e que foi levada presa na ocasião, quando tinha 15 anos, assim se referiu a um episódio de estresse que viveu alguns anos depois:

"Quando eu tive esse estresse, eu apaguei, e o que me vinha eram lembranças de holocausto, que eu nunca vivi e que, depois, inclusive, eu fui ver em filmes. Quer dizer, uma coisa de memória coletiva. [...] o que vinha, nesses delírios, eram exatamente memórias de judeus e de holocausto que eu não deveria ter, porque não sou judia” (PAIVA, 2013). Esse seminário resultou no livro Infância roubada (SÃO PAULO, 2014).

Ver a página eletrônica do Memorial da Resistência: http://www.memorialdaresistenciasp.org.br/memorial/\#. Acesso em: 14 jul. 2020. Em Alberti (2018), discuti possibilidades do Memorial da Resistência, do Arquivo Provincial da Memória de Córdoba, Argentina, e de outros memoriais na Educação em Direitos Humanos. 
de 1964. Não que não houvesse mobilização da sociedade civil e de setores do governo antes disso. Ao contrário: organizações como o Movimento Feminino pela Anistia (MFPA, criado em 1975) e o Comitê Brasileiro pela Anistia (CBA, de 1978) já vinham atuando desde os anos da ditadura. Ocorre que a ruptura com as instituições e os poderes do período ditatorial nunca se efetivou plenamente, ainda que a Constituição Federal de 1988 tenha sido um marco importante em direção a uma nova ordem democrática ${ }^{4}$.

\section{Ensino da ditadura em documentos oficiais}

Diferenças importantes são percebidas em nosso universo de ação quando nós, professores e professoras de História no Brasil ${ }^{5}$, lemos que na Argentina a Lei de Educação Nacional, de 2006, estabeleceu como conteúdo curricular “o estudo e a construção da memória coletiva sobre os processos históricos e políticos que romperam a ordem constitucional e acabaram por instaurar o terrorismo de Estado, de forma a gerar nos/as alunos/as reflexões e sentimentos democráticos e de defesa do Estado de Direito e o pleno cumprimento dos Direitos Humanos." (ARGENTINA, 2006 apud GONZALEZ, 2018, p. 62, tradução nossa) e que, a partir dessa lei, criaram-se núcleos de aprendizagens prioritárias, os quais, entre 2006 e 2012, indicaram os seguintes conteúdos para a educação secundária:

O conhecimento das características do terrorismo de Estado implementado na Argentina pela ditadura militar de 1976-1983 e de sua relação com a Guerra Fria e a aplicação de um modelo econômico e social neoliberal. (ARGENTINA, 2006 apud GONZALEZ, 2018, p. 62, tradução nossa)

A compreensão do golpe civil-militar de 1976 e do Terrorismo de Estado como um plano sistemático para destruir as organizações populares e disciplinar a sociedade, criando as condições para a implementação do modelo econômico neoliberal. (ARGENTINA, 2006 apud GONZALEZ, 2018, p. 62, tradução nossa)

\footnotetext{
${ }^{4}$ Sobre os antecedentes da CNV, ver Brasil (2014, v. I, p. 23-30).

5 Opto por utilizar "professor ou professora" e "alunos e alunas", neste texto, influenciada por comentários de Paulo Freire em Pedagogia da esperança. Posicionando-se contra a linguagem machista que adotara em Pedagogia do oprimido, Freire pergunta: "Como explicar, a não ser ideologicamente, a regra segundo a qual se há duzentas mulheres numa sala e só um homem devo dizer 'Eles todos são trabalhadores e dedicados'?". E defende: "Não é puro idealismo, acrescente-se, não esperar que o mundo mude radicalmente para que se vá mudando a linguagem. Mudar a linguagem faz parte do processo de mudar o mundo." (FREIRE, 2011, p. 93 e 94)
} 
Contudo, é bom lembrar que os relatórios da CNV e de outras comissões da verdade estaduais, municipais e institucionais que funcionaram no Brasil na década de 2010 são documentos oficiais que trazem recomendações importantes no que tange à Educação. Um estudo de 45 comissões da verdade estaduais e municipais que tiveram lugar entre 2011 e 2016 no Brasil demonstrou que:

Grosso modo, as recomendações se dividem entre ações de memória em relação aos crimes da ditadura (tais como a alteração de nome de logradouros públicos, a construção de memoriais de resistência, a apresentação de pedidos oficiais de desculpas, entre outros) e a criação institucional de meios "para que não se repitam" (tal como ações de justiça social e de continuação das investigações sobre crimes da ditadura, além de reformas das polícias, dos currículos escolares, dos sistemas de leis e justiça e dos meios de comunicação). (HOLLANDA; ISRAEL, 2019, p. 9-10)

O mesmo estudo constatou que os itens "ações de memória" e "reforma curricular (escolas)" foram os mais frequentes entre as recomendações.

O problema, para professores e professoras de História no Brasil, é que aparentemente os relatórios das comissões da verdade - documentos oficiais produzidos pelos poderes Legislativo e Executivo de estados e municípios e pelo Estado brasileiro (como é o caso do relatório da CNV) - tornaram-se letra morta. Em sua maioria, estão acessíveis na internet, assim como os documentos que encontraram e aqueles que produziram, mas são desconhecidos de grande parte das pessoas.

Além disso, e o que é pior, não são respeitados por muitas instituições de governo. Por exemplo, a recomendação número 4 do relatório da CNV consiste expressamente na "proibição da realização de eventos oficiais em comemoração ao golpe militar de 1964" (BRASIL, 2014, v. I, p. 967). Contudo, em 26 de março de 2019 o porta-voz da Presidência da República informou que o presidente determinara ao Ministério da Defesa que fizesse as comemorações devidas a essa data, ensejando prontamente uma reação do Ministério Público Federal (MPF), que, no dia seguinte, recomendou que as instituições militares se abstivessem de promover ou participar de qualquer manifestação em homenagem ao "período de exceção instalado a partir do golpe militar de 31 de março de 1964" (MPF, 2019). A recomendação do MPF citou, entre os diversos 
“considerando", a CNV - a qual, em seu relatório final, reconhecera "a prática de graves violações aos direitos humanos" no período e recomendara "a proibição da realização de eventos oficiais em comemoração ao golpe militar de 1964" (MPF, 2019). Em 31 de março de 2019 não houve comemorações ou homenagens, mas, ainda assim, o Ministério da Defesa publicou uma "Ordem do Dia Alusiva ao 31 de Março de 1964", afirmando que naquela data "foi interrompida a escalada em direção ao totalitarismo" e que as Forças Armadas, "atendendo ao clamor da ampla maioria da população e da imprensa brasileira, assumiram o papel de estabilização daquele processo" (BRASIL, 2019). Publicação de igual teor foi feita no ano seguinte, quando o mesmo Ministério da Defesa lançou outra "Ordem do Dia Alusiva ao 31 de Março de 1964", que começava com a seguinte frase: "o Movimento de 1964 é um marco para a democracia brasileira” (BRASIL, 2020).

Ser professor e professora de História nos últimos anos no Brasil tem sido um exercício constante de resistência e paciência, pois ações de governo como essas acabam legitimando pontos de vista antidemocráticos e de defesa da ditadura militar. Em geral, podemos dizer que os relatórios das comissões da verdade, ainda que constituam documentos oficiais, não parecem suficientes para respaldar nossas ações em sala de aula .

Já a Base Nacional Comum Curricular (BNCC) - que, no caso do ensino de História, jamais estará descolada do percurso tortuoso de sua elaboração (ver, entre outros, OLIVEIRA e FREITAS, 2018) - poderia, em princípio, respaldar algumas de nossas ações. A BNCC do Ensino Fundamental prevê, entre os "objetos de conhecimento" do currículo de História para o 9ㅇ Ano, "A ditadura civil-militar e os processos de resistência" e "As questões indígena e negra e a ditadura" (BRASIL, [2018], p. 430). As habilidades relativas a esses objetos de conhecimento são:

(EF09HI19) Identificar e compreender o processo que resultou na ditadura civil-militar no Brasil e discutir a emergência de questões relacionadas à memória e à justiça sobre os casos de violação dos direitos humanos.

\footnotetext{
Essa situação se tornou ainda mais grave com a crescente aceitação de ideias disseminadas pela associação Escola sem Partido. Ver: FRIGOTTO, Gaudêncio (org.). Escola "sem" partido: esfinge que ameaça a educação e a sociedade brasileira. Rio de Janeiro: Uerj, Laboratório de Políticas Públicas (LPP), 2017. Disponível em: https://drive.google.com/file/d/OB8ZDG4hi54IEZ05HQWdzUmViekE/view. Acesso em: 15 jul. 2020.
} 
(EF09HI20) Discutir os processos de resistência e as propostas de reorganização da sociedade brasileira durante a ditadura civilmilitar.

(EF09HI21) Identificar e relacionar as demandas indígenas e quilombolas como forma de contestação ao modelo desenvolvimentista da ditadura. (BRASIL, [2018], p. 431)

O problema, para professores e professoras do 9ㅇ Ano, contudo, é o fato de o currículo desse único ano abarcar conteúdos da história do Brasil, das Américas e do mundo de todo o século XX e do século XXI - até a "história recente". Ou seja, falta tempo para tratar das habilidades citadas, e de outras, com o cuidado que elas exigem.

A BNCC do Ensino Médio não arrola conteúdos históricos a estudar. Ela foi instituída no final de 2018, devendo ser implantada até 2022, e ainda é foco de muita dúvida e objeto de muita discussão. De acordo com o documento, estudantes do Ensino Médio poderão optar por itinerários formativos, sendo um deles as "Ciências Humanas e Sociais Aplicadas", sem que haja distinção das disciplinas que fazem parte desse conjunto. A habilidade mais aproximada do tema que nos ocupa aqui seria:

Identificar e caracterizar a presença do paternalismo, do autoritarismo e do populismo na política, na sociedade e nas culturas brasileira e latino-americana, em períodos ditatoriais e democráticos, relacionando-os com as formas de organização e de articulação das sociedades em defesa da autonomia, da liberdade, do diálogo e da promoção da democracia, da cidadania e dos direitos humanos na sociedade atual. (BRASIL, [2018], p. 579)

As Diretrizes Nacionais para a Educação em Direitos Humanos estabelecidas pelo Conselho Nacional de Educação (CNE) em maio de 2012 são outro exemplo de documento oficial que pode ser trazido para nossa prática docente ${ }^{7}$. Podemos identificar alguma ressonância delas em documentos posteriores do Ministério da Educação (MEC), como é o caso da própria BNCC, onde é recorrente a expressão "direitos humanos" (uma pesquisa rápida identificou 63 ocorrências). Os 2 primeiros itens do art. 4o das Diretrizes Nacionais para a Educação em Direitos Humanos são especialmente importantes para nós. Apesar de não mencionarem especificamente a ditadura militar, podemos dizer que eles acolhem o tema: 
Art. 4ำ A Educação em Direitos Humanos como processo sistemático e multidimensional, orientador da formação integral dos sujeitos de direitos, articula-se às seguintes dimensões:

I - apreensão de conhecimentos historicamente construídos sobre direitos humanos e a sua relação com os contextos internacional, nacional e local;

II - afirmação de valores, atitudes e práticas sociais que expressem a cultura dos direitos humanos em todos os espaços da sociedade. (BRASIL, 2012)

Documentos oficiais brasileiros podem não ser incisivos o suficiente na abordagem do ensino da ditadura; contudo, precisamos conhecê-los, pois constituem instrumentos importantes para defendermos nossas práticas docentes perante toda a comunidade escolar.

O que gostaríamos que nossos alunos e nossas alunas aprendessem?

Quando nós, professores e professoras de História, começamos um novo tópico em nossas aulas, sempre convém precisar, para nós mesmos(as), aquilo que consideramos ser fundamental que nossas turmas aprendam. Creio que, ao ensinar a ditadura militar, uma das questões com as quais precisamos lidar é a ideia distorcida de que os crimes cometidos pelo Estado são da mesma ordem que aqueles que teriam sido cometidos pelas organizações que resistiram à ditadura - aquilo conhecido na Argentina por "teoria dos dois demônios" (GONZÁLEZ, 2018) e que no Brasil geralmente aparece sob o argumento de que também é preciso considerar "o outro lado", como se "dois lados" equivalentes tivessem se confrontado durante o período (e como se, na história e na vida em sociedade, sempre houvesse apenas dois lados e não uma multiplicidade de perspectivas).

Três horizontes de argumentação podem nos ajudar nessa questão:

1) Comparar as ações das organizações que resistiram à ditadura com as ações da resistência contra o nazismo que ocorreram na Alemanha e nos países por ela ocupados. Em 8 de novembro de 1939, uma tentativa malograda de atentado contra Adolf Hitler em Munique matou 8 pessoas e causou ferimentos em outras 63. Seu autor, Johann Georg Elser, logo foi capturado e preso, sendo executado quase no final da guerra (1939: ATENTADO..., 2019). Em 20 de julho de 1944, outro atentado 
malogrado resultou na morte de seu autor, Claus Schenk von Stauffenberg (que havia sido um fervoroso nacional-socialista), sendo seguido pela morte de outros 200 membros da resistência (HASSELBACH, 2019). Podemos supor que dificilmente as mortes e os ferimentos causados pelo primeiro atentado sejam equiparados às mortes dos 200 membros da resistência, isto é, que ações da resistência sejam consideradas da mesma ordem que os crimes cometidos pelo Estado. Como já tive oportunidade de escrever alhures:

Quando ouvimos relatos de pessoas que resistiram à ditadura organizando transportes de armas, realizando atentados e sabotagens, algumas vezes achamos que essas atitudes podem não ter sido corretas. Mas quando nos damos conta de que muitas pessoas praticaram essas ações para resistir à ditadura nazista, percebemos que, nesse caso, isso geralmente não é visto como incorreto. Por que será que ocorre essa diferença de visão? (ALBERTI, 2018, p. 129)

Evocar a resistência armada ao nazismo pode ser útil para colocar em perspectiva as ideias muitas vezes veiculadas a respeito da resistência armada à ditadura militar no Brasil; contudo, isso não significa justificar ou endossar a violência por princípio.

2) Compreender que o Estado democrático de direito e seus agentes não podem cometer violações dos direitos humanos. Essa compreensão não é instantânea, evidentemente, ainda mais quando a ideia de que "bandido bom é bandido morto" está espalhada em diferentes setores da sociedade. Aqui, um estudo concentrado nos direitos humanos pode ajudar a entender que cabe ao Estado respeitar os direitos humanos (o Estado não deve violar os direitos humanos); proteger os direitos humanos (impedir que esses direitos sejam violados por quem quer que seja) e implementar os direitos humanos (tomar medidas para que esses direitos possam ser exercidos plenamente por todas as pessoas) (VIEIRA; GHIRARDI; FEFERBAUM, 2017, p. 35-36)8.

3) Trabalhar exemplos de violações de direitos humanos cometidas pelo Estado durante a ditadura e que atingiram pessoas que não pegaram em armas para resistir ao regime. Esses exemplos podem ajudar a

\footnotetext{
3 Em 2018, ano em que a Declaração Universal dos Direitos Humanos (DUDH) completou 70 anos, tive oportunidade de fazer um estudo sobre o assunto, com minhas turmas da Educação Básica e do Ensino Superior, com base no livro de Vieira, Ghirardi e Feferbaum (2017). Efemérides como essa - 70 anos da DUDH - também são boas formas de legitimar estudos sobre determinados temas.
} 
desmontar a ideia equivocada de que a violência do Estado ocorreu em reação à violência de grupos armados. Um recurso pode ser o livro Infância roubada (SÃO PAULO, 2014), resultado do seminário "Verdade e Infância Roubada: Crianças Atingidas pela Ditadura”, realizado em 2013 no âmbito da Comissão Estadual da Verdade de São Paulo. Esse livro está disponível na internet, o que facilita sua consulta. Alunos e alunas, individualmente ou em grupo, podem escolher depoimentos ali incluídos e produzir algum resultado a partir de sua investigação: um cartaz, um poema, um desenho, um esquete de teatro, uma música ou mesmo uma apresentação para o restante da classe. As histórias são relativamente curtas e acompanhadas de documentos escritos e iconográficos, o que pode estimular sua leitura. O fato de os e as estudantes terem de escolher uma delas para trabalhar permite que tenham contato com alguns dos depoimentos e estabeleçam critérios de escolha, mesmo que não explicitados. Outro exemplo pode girar em torno das violações cometidas contra indígenas antes e durante a ditadura. Dois recursos podem ser úteis nesse caso: uma reportagem de Norman Lewis publicada em 1969 na Sunday Times Magazine (LEWIS, 1969) e o capítulo "Violações de direitos humanos dos povos indígenas", que consta no volume $\|$ do relatório da CNV (BRASIL, 2014, v. II, p. 203-262). Trata-se de 2 textos bastante extensos que talvez tenham de ser condensados pelo professor ou pela professora antes de serem propostos às turmas. (Convém observar que os trabalhos de pesquisa e produção de documentos realizados pelas comissões da verdade são um verdadeiro manancial de recursos que podemos usar nas nossas aulas de História. É o caso, aqui, dos depoimentos reunidos no livro Infância roubada e da parte do relatório da CNV referente à violação dos direitos humanos dos povos indígenas.)

O que estou denominando aqui três horizontes de argumentação são mesmo "horizontes", ou seja, algo que permaneça em nosso campo de visão durante o estudo da ditadura militar com nossas turmas. Podemos ou não trabalhar especificamente esses pontos, mas é importante que estejam à mão, dependendo das inquietações e demandas dos e das estudantes.

E o que mais gostaríamos que nossos alunos e nossas alunas aprendessem a respeito da ditadura militar no Brasil? Muitas respostas são possíveis. Para além do processo político que resultou no golpe e dos diferentes 
acontecimentos e conjunturas econômicos, sociais e políticos dos 21 anos de ditadura, penso que precisamos discutir com nossas turmas a Lei de Anistia (de 28 de agosto de 1979) - sancionada ainda durante a ditadura -, a manutenção de sua interpretação pelo Supremo Tribunal Federal (STF) (de 29 de abril de 2010) e a instituição das comissões da verdade, especialmente da CNV. Há muitas ideias equivocadas sobre esse processo, como, por exemplo, a de que todas as pessoas perseguidas pelo regime teriam sido anistiadas em 1979. Em 7 de agosto daquele ano, quando o projeto de lei estava sendo discutido no Congresso Nacional, o Jornal do Brasil noticiou que o Superior Tribunal Militar (STM) estimava que 320 pessoas estariam "fora da anistia" "por terem sido condenadas, com processo em julgado, pela prática de crimes de terrorismo, sequestro, assalto a banco e ações de devastação e saqueamento" (STM CALCULA..., 1979, p. 13). A anistia, sabemos, não foi "ampla, geral e irrestrita", como reivindicavam os Comitês Brasileiros pela Anistia (CBAs). Além disso, a lei foi interpretada de tal forma que acabou anistiando agentes públicos, militares e civis, que cometeram crimes contra pessoas que se opuseram à ditadura?

Todas essas questões nos levam a discutir a incipiente Justiça de Transição pela qual passamos no Brasil e as formas como as pessoas se lembram da ditadura ${ }^{10}$. Já tive oportunidade de escrever que "as disputas em

\footnotetext{
9 Em 2014, quando "comemorávamos" 50 anos do golpe militar no Brasil, trabalhei com minhas turmas do Ensino Médio um projeto de votação simbólica de revisão da Lei de Anistia, experiência sobre a qual pude refletir. Ver: ALBERTI, Verena. "Votação simbólica do projeto de revisão da Lei de Anistia: uma experiência no ensino médio." Trabalho apresentado na mesa redonda "Por que ensinar ditaduras do século XX?", durante o seminário internacional "O ensino das ditaduras em tempos democráticos”, promovido pelo Núcleo de Pesquisa História e Ensino das Ditaduras, na Universidade Federal Fluminense. Niterói, de 26 e 28 de agosto de 2014. Disponível em: http://bibliotecadigital.fgv.br/dspace/handle/10438/17192: Acesso em: 15 maio 2020; ALBERTI, Verena. "O professor de história e as questões sensíveis e controversas." Palestra proferida no IV Colóquio Nacional História Cultural e Sensibilidades realizado no Centro de Ensino Superior do Seridó (Ceres) da Universidade Federal do Rio Grande do Norte (UFRN), em Caicó (RN), de 17 a 21 de novembro de 2014. Disponível em: http://bibliotecadigital.fgv.br/dspace/handle/10438/17189. Acesso em: 12 jul. 2020.

${ }^{10} \mathrm{Em}$ trabalho apresentado ao XI Encontro Nacional de Pesquisadores do Ensino de História relatei discussões que pude estabelecer a respeito com minhas turmas de formação de professores na Universidade do Estado do Rio de Janeiro (UERJ) em 2017. Ver: ALBERTI, Verena. "Paulo Freire ao pé da letra: da doxa ao logos como caminho possível no estudo de história." Encontro Nacional de Pesquisadores do Ensino de História. (11: 2017: Rio de Janeiro, RJ). Anais do XI Encontro Nacional de Pesquisadores do Ensino de História: Pesquisa em Ensino de História, desafios de um campo de conhecimento/ Coordenação de Ana Maria Ferreira da Costa Monteiro. - Rio de Janeiro: UFRJ. Faculdade de Educação; ABEH, 2018. 357p. p. 205-215. Disponível em https://xienpeh.ufrj.br/wp-content/uploads/anais xi enpeh final.pdf, acesso em 12/7/2020.
} 
torno de memórias são assunto que mobilizam enormemente as sociedades no presente" e que, por isso mesmo, "é importante que sejam tratadas na escola" (ALBERTI, 2015). Se houver tempo e condições, as ordens do dia alusivas ao 31 de Março de 1964 publicadas pelo Ministério da Defesa (BRASIL, 2019, 2020) também podem ser trabalhadas. Para os propósitos das aulas de História, elas têm a vantagem de serem curtas e de estarem disponíveis na internet; podem ser analisadas em um tempo de aula, em grupos ou não, ou trabalhadas em casa.

\section{Possibilidades do trabalho com documentos: para além das "lições" sobre o passado ${ }^{11}$}

As ordens do dia publicadas pelo Ministério da Defesa são documentos. O trabalho com documentos, sejam fontes primárias ou secundárias, é fundamental para as aulas de História. Como já escrevi em outra ocasião:

O trabalho com fontes é tão importante para as aulas de história quanto são as experiências em laboratório para as aulas de química, física ou biologia. De um lado, porque (i) ele permite ampliar o conhecimento sobre o passado e, de outro, porque (ii) possibilita que alunos e alunas percebam, na prática, como se constitui o conhecimento histórico. (ALBERTI, 2019, p. 107)

No caso do nosso tema, o trabalho com documentos pode nos ajudar a evitar a armadilha de tirar lições do passado sem elaborar aprendizados efetivos.

Vejamos a análise que faz Federico Lorenz $(2004,2006)$ da construção da memória do episódio La noche de los lápices, na Argentina, e de sua inserção no ensino. Em 16 de setembro de 1976, 6 meses depois de instituída a ditadura militar na Argentina, um grupo de 10 estudantes secundaristas, que tinham entre 16 e 19 anos, foi sequestrado pelas Forças Armadas na cidade de La Plata e submetido a torturas em diferentes centros clandestinos; 6 deles continuam desaparecidos. Entre outras ações políticas, o grupo havia participado da luta pelo boleto estudantil secundarista, que garantia a redução da passagem de

Nesta parte e nas seguintes, recupero discussões que tive oportunidade de fazer na apresentação "O trabalho com documentos no estudo da ditadura", na mesa "Arquivos, ensino e lugares de memória na Ditadura”, durante o III Simpósio Internacional "Brasil: Da Ditadura à Democracia”, na Pontifícia Universidade Católica do Rio de Janeiro (PUC-Rio), de 9 a 11 de agosto de 2017. Ver folder em http://www.his.puc-rio.br/wp-content/uploads/larissa-3-folder.pdf. Acesso em: 12 jul. 2020. 
ônibus para estudantes de baixa renda. Em maio de 1985, pouco mais de 1 ano após o fim da ditadura militar na Argentina (que ocorreu em dezembro de 1983), o episódio, que até então era muito pouco conhecido, passou à esfera pública, porque um dos sobreviventes, Pablo Díaz, testemunhou no processo judicial contra as Juntas Militares, acusadas de graves violações dos direitos humanos. No ano seguinte, em 1986, foram lançados 1 livro e 1 filme sobre o assunto, ambos intitulados La noche de los lápices, nome pelo qual o caso ficou conhecido ${ }^{12}$.

Federico Lorenz $(2004,2006)$ avalia que, durante os anos 1980, consolidouse o modelo de denúncia dos crimes da ditadura militar, e o caso da Noche de los lápices funcionou como uma via para que se falasse da ditadura nas escolas, com apoio do livro e do filme. Em 1988, uma lei da província de Buenos Aires tornou o 16 de setembro o "Dia dos direitos do estudante secundário", em homenagem ao dia em que os estudantes foram sequestrados ${ }^{13}$. Em entrevista concedida ao periódico Página 12 em 16 de setembro de 2003, Lorenz afirmava:

A cada dia 16 de setembro os professores têm que dedicar o dia
para refletir sobre os acontecimentos de La Noche ... Para muitos,
a saída automática era exibir o filme de mesmo nome. E como
àquela altura do ano o tema da ditadura como tal não era
abordado, a história dos estudantes que reivindicam o boleto
estudantil ficou trancada na própria história do filme, sem um
contexto que explicasse a ação repressiva. (MUCHO..., 2003,
tradução nossa)

Essa situação tem a ver com o próprio momento da transição democrática na Argentina, em que a demanda social pelo "dever de memória" era fortemente condicionada pelo ético, diz Federico Lorenz. Em rememorações desse tipo, observa, tendemos a recordar mais atitudes e símbolos, em vez de épocas e processos. O resultado é que perdemos as dimensões históricas, e o episódio se traslada para um espaço atemporal. Ou seja, as graves violações dos direitos humanos são denunciadas, mas não se discute a situação histórica e política que as fez possíveis. Ademais, a ênfase na denúncia pode levar a um efeito

\footnotetext{
12 Sobre a história da memória desse episódio, ver: TOLENTINO, Marcos Oliveira Amorim. Os outros rostos de 'La Noche de los Lápices': memória e testemunho dos sobreviventes de um episódio emblemático da repressão durante a última ditadura civil-militar argentina (1976-1983). História Oral, v.17, n.1, $\quad$ p. $\quad$ 89-117, $2014 . \quad$ Disponível em: https://revista.historiaoral.org.br/index.php/rho/article/view/340. Acesso em: 15 jul. 2020.

A respeito da lei, ver http://www.gob.gba.gov.ar/legislacion/legislacion/l-10671.html e http://www.libros.uchile.cl/files/presses/1/monographs/379/submission/proof/files/assets/basi c-html/page115.html. Acesso em: 15 jul. 2020.
} 
indesejado: a ideia de que a existência de algo chamado "direitos humanos" se restrinja ao passado (LORENZ, 2006; MUCHO..., 2003) $)^{14}$.

Reflexão semelhante foi feita por Paul Salmons, diretor de programa do Centro para a Educação do Holocausto do University College London ${ }^{15}$. Na Inglaterra, como em muitos países, o ensino do holocausto é obrigatório. Paul Salmons observa com frequência que não podemos nos contentar em emocionar os estudantes; é preciso ir além da sensibilização e promover um trabalho intelectual, de modo que haja produção de conhecimento histórico ${ }^{16}$.

Uma pesquisa realizada entre 2008 e 2009 com mais de 2.100 professores da Educação Básica na Inglaterra mostrou que esses professores consideravam mais importante "aprender as lições do holocausto" para que tais atrocidades nunca mais se repetissem - ou seja, uma abordagem ética do ensino do holocausto - do que compreender as ações de pessoas envolvidas e afetadas por esse evento e aprofundar o conhecimento sobre a Segunda Guerra e o século $X X$ - isto é, uma abordagem que permita a compreensão histórica (SALMONS, $2010)^{17}$.

Concordo com Paul Salmons, quando afirma que um estudo do holocausto que ignore uma abordagem histórica explícita não só corre o risco de distorcer o passado e abrir mão de significados mais complexos, mas deixa os estudantes vulneráveis a manipulações daqueles que usam o passado para impulsionar suas próprias agendas sociais ou políticas.

Deduzir do estudo do holocausto que "guerra é ruim", que "racismo é errado" e que "o mal deve ser confrontado" é simplificar o tema e, como alertou Federico Lorenz em relação à Noche de los lápices, transferi-lo para um espaço atemporal. Os valores morais que se costuma sublinhar nesse tipo de abordagem

\footnotetext{
14 Já tive oportunidade de discutir a questão da Noche de los lápices e a reflexão que Lorenz faz a respeito em Alberti (2015).

${ }^{15}$ Ver https://www.holocausteducation.org.uk/. Acesso em: 4 ago. 2017.

16 Já tive oportunidade de escrever sobre isso em: ALBERTI, Verena. Dois temas sensíveis no ensino de história e as possibilidades da história oral: a questão racial e a ditadura no Brasil. In: RODEGHERO, Carla Simone; GRINBERG, Lúcia; FROTSCHER, Méri. História oral e práticas educacionais. Porto Alegre: Editora da UFRGS, 2016. p. 35-60.

17 Sobre a pesquisa, ver: PETTIGREW, Alice; FOSTER, Stuart. Teaching about the holocaust in english secondary schools: an empirical study of national trends, perspectives and practice. London: Institute of Education, University of London, 2009. Disponível em: https://www.holocausteducation.org.uk/wp-content/uploads/Final-Report-Master-Document19-October-2009__HIMONIDES_.pdf. Acesso em: 4 ago. 2017.
} 
- ideias de coragem, boa vontade, tolerância etc. - são os mesmos desde o Iluminismo e não foram suficientes para prevenir esse e outros genocídios (SALMONS, 2010).

Para Salmons (2010), apenas uma sólida abordagem disciplinar - isto é, histórica - pode fornecer formas efetivas de conhecimento do mundo. É preciso, diz ele, restaurar a complexidade do passado, pois

[...] é na dissonância cognitiva entre como achamos que o mundo devia ser e como ele se descortina para nós quando exploramos a complexidade do passado que abrimos espaço para o aprendizado efetivo: não apenas absorvendo uma nova informação, mas sendo obrigados a reordenar nossas categorias e entendimentos. (SALMONS, 2010, p. 60)

Em síntese, essas duas reflexões sobre como trabalhar o estudo de ditaduras nas aulas de História chamam a atenção para o risco da "pasteurização" de abordagens éticas, de abordagens não históricas, ou atemporais. "Pasteurizar", como lembra o Dicionário Houaiss da língua portuguesa, é "empobrecer (uma obra, uma teoria etc.) com o intuito de agradar ao público ou tornar sua mensagem mais chã" (HOUAISS; VILLAR, 2009), isto é, mais rasa, rasteira.

Como restaurar a complexidade do passado e evitar um aprendizado raso e rasteiro sobre a ditadura? Uma possibilidade de resposta é: trabalhando com documentos. É claro que não há aqui nenhuma novidade; muitos(as) professores(as) e pesquisadores(as) de ensino de História têm insistido na importância do trabalho com documentos. Mas o que pode parecer óbvio para nós não o é em muitas salas de aula. Ensinar História ainda é, para muitos estudantes, pais e colegas, transmitir o passado. Como observou Christian Laville (2002, p. 19), "para alguém que não é íntimo da história, ela se apresenta essencialmente sob a forma de narrativa transmitida pelo historiador".

No final dos anos 1960 e início dos anos 1970, operou-se uma importante mudança no campo do ensino da História em alguns países. Mais importante do que "transmitir o passado" passou a ser ensinar a "pensar historicamente". Para tornar isso factível, alguns professores e algumas professoras têm distinguido entre, de um lado, os conceitos identificados com a "matéria" da História (como "revolução", "ditadura", "Primeira Guerra" etc.) e, de outro, os conceitos relacionados com operações intelectuais específicas da produção do 
conhecimento histórico, como causalidade, tempo histórico, mudança e continuidade, interpretação, diversidade e relevância. Os dois tipos de conceitos são aprendidos concomitantemente. Por exemplo: estudar a Primeira Guerra e o conceito de causalidade (Uma bala pode provocar uma guerra?). Além disso, o aprendizado se dá a partir de problemas, ou perguntas de pesquisa, que serão resolvidos (ou não) com o uso de fontes ou evidências, processo que desemboca na produção de resultados (ensaio, peça de teatro, blog, apresentação etc.). As perguntas de pesquisa procuram acionar os diferentes conceitos das operações intelectuais. Por exemplo, além da causalidade (Uma bala pode provocar uma guerra?), a Primeira Guerra pode ser estudada considerando o conceito de relevância (Por que devemos estudar a Primeira Guerra?). Tal processo (perguntas de pesquisa, trabalho com fontes e produção de resultado) enseja a possibilidade de produção de conhecimento, permitindo que o aluno e a aluna reflitam sobre como se constitui o conhecimento histórico ${ }^{18}$.

\section{Uma experiência em aulas de História: explorando o conceito de diversidade}

Em 2017, tive oportunidade de trabalhar com documentos com minhas turmas do 3ำ Ano do Ensino Médio, após as férias de julho ${ }^{19}$. Aproveitando que estávamos estudando a ditadura militar desde junho, dediquei algumas aulas de agosto à análise de documentos que haviam sido levantados em uma pesquisa sobre material didático e história da memória da ditadura militar ${ }^{20}$.

\footnotetext{
${ }^{18}$ A respeito dos conceitos e práticas envolvidos nesse processo, ver: ALBERTI, Verena. O ensino de história na Inglaterra: conceitos e práticas. In: FERREIRA, Marieta de Moraes (org.). Memória e identidade nacional. Rio de Janeiro: Editora FGV, 2010. p. 81-100.

19 Ver, também: ALBERTI, Verena. Material didático sobre a história e a memória da ditadura militar no âmbito da educação dos direitos humanos. Trabalho apresentado no Simpósio Temático ST 031 "Ensino de História, Currículo e Cultura: narrativas em disputa", que integrou a programação do XXIX Simpósio Nacional de História - Contra os Preconceitos: História e Democracia, promovido pela Associação Nacional de História (Anpuh-Brasil), ocorrido entre os dias 24 e 28 de julho de 2017, na Universidade de Brasília. Disponível em http://www.snh2017.anpuh.org/resources/anais/54/1502756916 ARQUIVO textoVerenaAlbertian puh2017.pdf.

${ }^{20}$ A pesquisa, que contou com a participação da então bolsista Aline Diogo de Melo, fez parte do projeto "Arqueologia da reconciliação: formulação, aplicação e recepção de políticas públicas relativas à violação de direitos humanos durante a ditadura militar”, coordenado pela professora Angela Moreira da Escola de Ciências Sociais da Fundação Getulio Vargas (FGV) entre 2014 e 2016. O projeto foi apoiado pela Fundação de Amparo à Pesquisa do Estado do Rio de Janeiro (FAPERJ), em convênio com a Comissão Estadual da Verdade (CEV) do Rio, no âmbito do programa "Apoio ao estudo de temas relacionados ao direito à memória, à verdade e à justiça relativos a violações de direitos humanos no período de 1946 a 1988", lançado pelo Edital n. 38/2013.
} 
Iniciei com um exercício de que gosto muito - analisar um documento a partir de níveis de inferência:

1. O que o documento diz?

2. O que posso inferir?

3. O que ele não diz?

4. O que e onde podemos saber mais?

Essas 4 perguntas de aproximação do documento podem ser combinadas com aquelas mais voltadas à intenção de sua produção e de sua preservação: quem, por que, quando, para quem, como o produziu e/ou o preservou? ${ }^{21}$

Em uma primeira aula eu me ocupei, com minhas turmas, de apenas 1 documento, depositado no Arquivo Nacional e que faz parte do acervo consultado pela CNV (Figura 1).

Figura 1 - Motorista policial João Rosa da Cruz presta informação

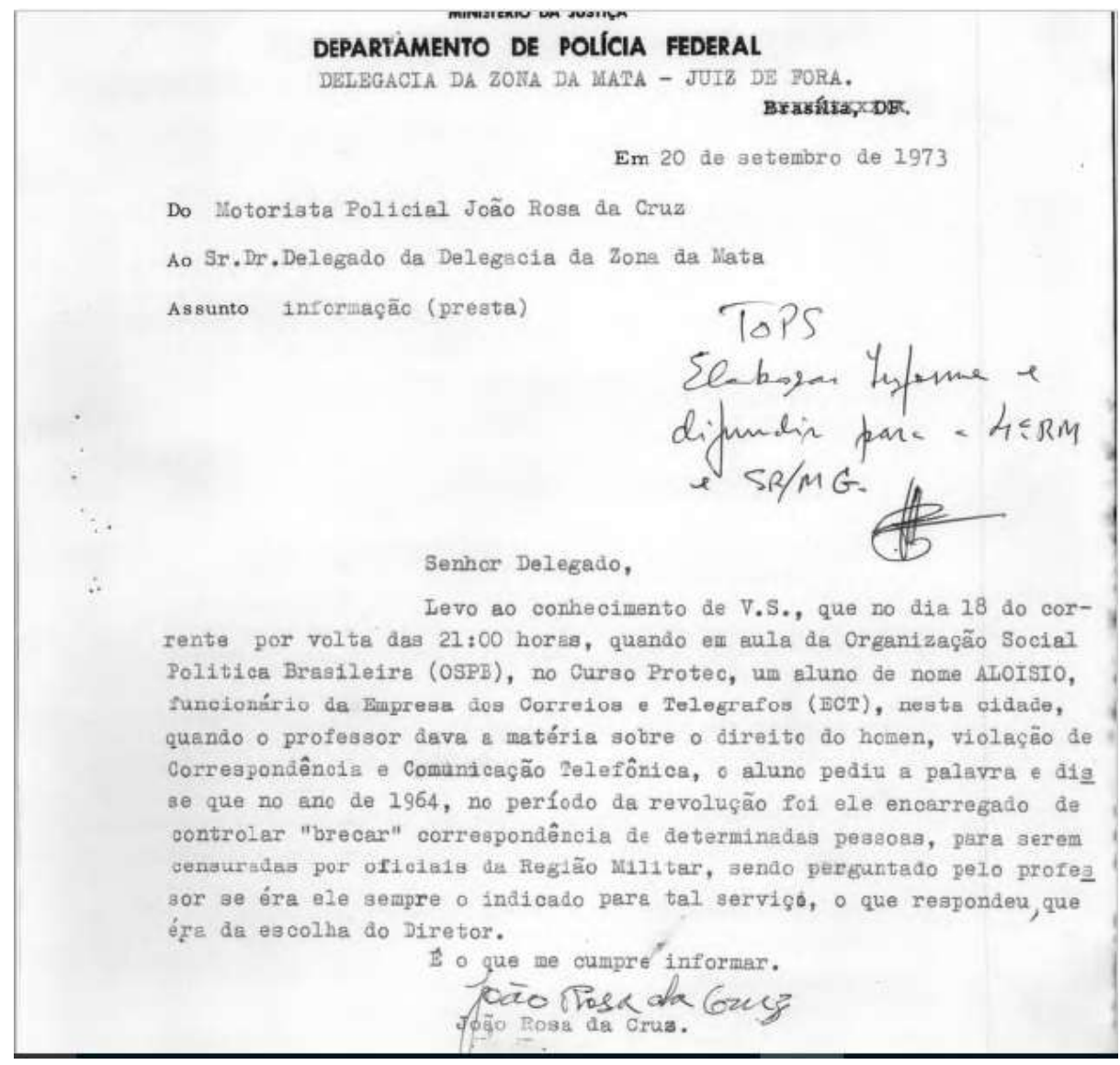

Fonte: CONSELHO DE SEGURANÇA NACIONAL. Delegacia da Polícia Federal em Juiz de Fora_Investigações. Juiz de Fora: Departamento de Polícia Federal, 1973. p. 574. Acervo Arquivo Nacional: BR_DFANBSB_HE_O_IVT_0015.pdf.

\footnotetext{
${ }^{21}$ Sobre essa abordagem de documentos, ver ALBERTI, 2019.
} 
Atentamos não só para o conteúdo do documento, mas para sua forma: as inscrições que faziam parte do papel timbrado e aquelas que foram feitas pelo autor da carta, bem como as partes manuscritas. Alguns alunos foram bastante atentos e observaram, por exemplo, que o documento não diz quais foram as "determinadas pessoas" cuja correspondência foi controlada ("brecada") em 1964. Pudemos inferir, a partir do documento, que havia uma rotina de controle e distribuição de informes e que o próprio texto da carta, apesar de indicar alguma distância da norma culta, demonstrava certa adequação a um padrão de relatório, que possivelmente foi aprendido por seu autor. Também nos perguntamos por que o autor da carta e o delegado consideraram a informação digna de nota.

Em um segundo momento, levantamos todos os personagens citados ou envolvidos no documento. Foi muito interessante observar como os alunos e as alunas descobriram vários deles, além dos óbvios "motorista policial João Rosa da Cruz", "delegado", "aluno de nome Aloisio" e "professor”. Também surgiram o “diretor da Empresa de Correios e Telégrafos", as pessoas cuja correspondência foi violada, os oficiais da Região Militar que censuravam as cartas e o(a) destinatário(a) do bilhete manuscrito. O objetivo desse exercício foi trabalhar, em momento posterior, o conceito de diversidade, com base na tríade "adesão, acomodação e/ou resistência" sugerida por Rodrigo Patto Sá Motta, cuja entrevista ao site Café História (DITADURA..., 2017) pudemos percorrer rapidamente.

Em uma segunda aula, aprofundamos o estudo de documentos do regime militar com base nos níveis de inferência. Levei para algumas turmas reproduções de diferentes documentos. Divididos em grupos, os alunos e as alunas escolheram com qual documento gostariam de trabalhar e puseram-se a analisá-lo procurando responder às perguntas "o que o documento diz", "o que podemos inferir" etc. Foi importante disponibilizar uma variedade de documentos e possibilitar que fossem escolhidos. Isso permite o contato com diferentes documentos, o exercício da autonomia e a legitimação da capacidade de escolha. Possibilita um engajamento maior do que se o professor ou a 
professora distribuir um documento para cada grupo. Os alunos também foram solicitados a indicar quais pessoas, ou tipos de pessoa, sobressaíam nos documentos, a fim de que pudéssemos, adiante, trabalhar a diversidade de experiências e de atuações durante a ditadura.

Diversidade é um conceito relacionado às operações intelectuais específicas do conhecimento histórico: as sociedades são diversas, há diferentes grupos com diferentes interesses e perspectivas. No entanto, é comum ouvirmos nossos alunos e nossas alunas formularem frases que começam com um "Eles" genérico, como se as sociedades fossem formadas por um só grupo homogêneo 22 . A diversidade se aprende no contexto de diferentes "conteúdos" da história, e a melhor forma de aprender esse conceito é produzindo conhecimento a partir de desafios ou propostas de pesquisa. Como era viver na ditadura? Até que ponto a vida das pessoas mencionadas nos documentos foi afetada pela ditadura? Como podemos qualificar sua posição em relação ao regime: adesão, acomodação ou resistência? Vale ponderar que cada um dos termos dessa tríade também pressupõe gradações (maior ou menor adesão, maior ou menor acomodação, maior ou menor resistência).

Com essa espécie de exercício, talvez tenhamos em nossas aulas menos perguntas do tipo “como a população reagiu ao Al-2?”, que tive oportunidade de ouvir um dia ${ }^{23}$. A expectativa de resposta embutida em uma pergunta desse tipo denuncia que o aluno ou a aluna pressupõe a existência de "uma" população homogênea com uma única reação ao Al-2. Quando alunos e alunas exercitam a diversidade, é possível que esse tipo de raciocínio se torne cada vez mais raro. E, assim, podemos vislumbrar a progressão em história, coisa que, por vezes, é

\footnotetext{
22 Um dos números da revista Teaching History, da Associação de História do Reino Unido, voltado ao conceito de diversidade, teve o sugestivo subtítulo "To they or not to they", em alusão justamente ao uso exaustivo do pronome "eles” pelos estudantes. To 'They' or not to 'They' edition. Teaching History. The Historical Association UK. Londres, N. 135, June 2009. Disponível para associados em https://www.history.org.uk/secondary/resource/2440/teaching-history135-to-they-or-not-to-they. Acesso em: 7 ago. 2021.

${ }^{23}$ O Ato Institucional n. 2 (Al-2) foi decretado pelo regime militar em 17 de outubro de 1965. Ele determinava, entre outras medidas, eleições indiretas (por maioria do Congresso Nacional, voto aberto) para os cargos de Presidente e Vice-Presidente da República e a extinção dos partidos políticos que existiam desde 1945-1946. Além disso, o presidente poderia ordenar o recesso do Congresso e legislar por decretos e a Justiça Militar passou a julgar civis acusados de crime contra a segurança nacional.
} 
considerada impossível de existir, pois não se imagina que o aluno e a aluna possam aprender a pensar historicamente. O aprendizado efetivo, dizia Paul Salmons (2010, p. 60) no trecho citado anteriormente, dá-se não só quando "absorv[emos] uma nova informação", mas quando somos "obrigados a reordenar nossas categorias e entendimentos".

A identificação de pessoas, ou tipos de pessoas, implicadas em cada um dos documentos permite o aprendizado de diferentes conceitos. O ideal seria transpor os casos para fichas contendo uma breve caracterização e a data de atuação. O aluno de nome Aloisio receberia 2 fichas: uma para 1964, quando era encarregado de "brecar" a correspondência de "determinadas pessoas", e outra para 1973, quando assistia à aula de Organização Social e Política Brasileira (OSPB).

Para trabalhar o conceito de diversidade, as fichas podem ser dispostas em um diagrama de gradação, como em um eixo de $x$ e $y$, sendo que os "valores" de $x$ seriam "adesão", "acomodação" e "resistência" e os extremos de y seriam "mais afetado(a)" e "menos afetado(a)" pela ditadura. Os alunos e as alunas discutiriam entre si a posição de cada um dos personagens-casos, sem que houvesse, evidentemente, uma única resposta correta para a disposição das fichas no diagrama.

\section{Evidências de censura e o conceito de causalidade}

Outro conceito que pode ser trabalhado a partir da análise de documentos é o de causalidade. Uma pergunta de pesquisa instigante, nesse sentido, seria "por que a ditadura militar demorou 21 anos?" Entre os documentos que podem ajudar a responder a essa pergunta estão os muitos registros da atividade de censura. Há no Arquivo Nacional, entre os documentos consultados pela CNV, uma série de radiogramas expedidos diariamente pela Polícia Federal (PF) aos órgãos de comunicação, especificando proibições e restrições. O interessante é que as proibições não recaem apenas sobre assuntos que poderiam ser julgados "subversivos". Uma portaria do Ministro dos Transportes, o caso Ana Lídia (crime de estupro, tortura e assassinato de uma menina de 7 anos de idade, em Brasília), 
o surto de meningite e outros assuntos não vinculados à resistência à ditadura figuravam periodicamente entre as proibições. Mas também, como é o caso do primeiro exemplo a seguir, denúncias, feitas no exterior, das graves violações dos direitos humanos cometidas pelo Estado brasileiro. Os radiogramas reproduzidos nas figuras 2-8 são de 1974. No verso de cada folha (que não está registrado aqui), representantes de diferentes meios de comunicação assinavam em lista, atestando estarem cientes das proibições.

Figura 2 - Radiograma do Departamento de Polícia Federal para órgãos de imprensa, rádios e TVs, datado de 8 de abril de 1974

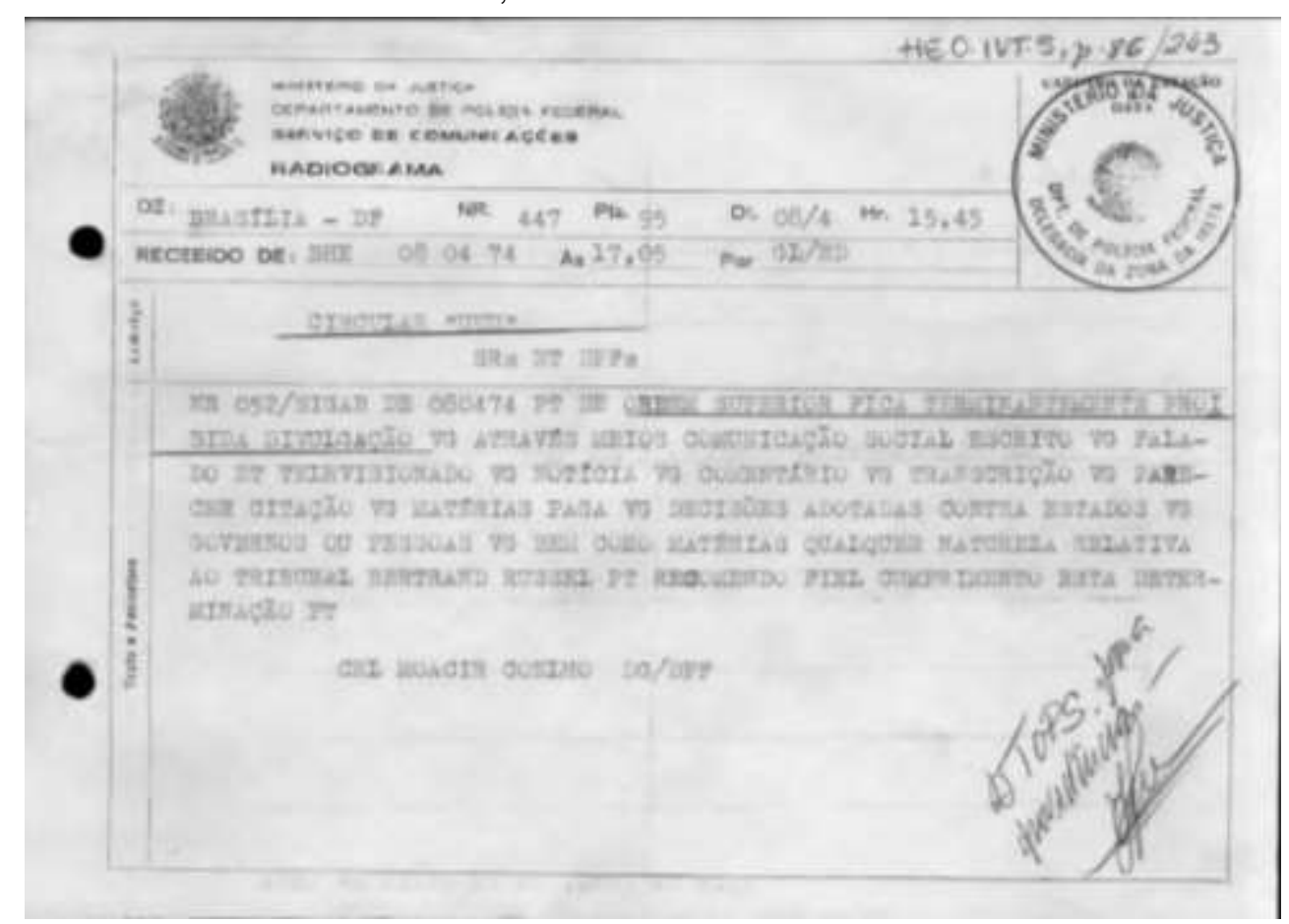

Fonte: CONSELHO DE SEGURANÇA NACIONAL. Delegacia da Polícia Federal de Juiz de Fora. Juiz de Fora: Departamento de Polícia Federal, 1974. Acervo Arquivo Nacional: pasta BR_DFANBSB_HE_O_IVT; documento BR_DFANBSB_HE_O_IVT_0005.pdf. 
Figura 3 - Radiograma do Departamento de Polícia Federal para órgãos de imprensa, rádios e TVs, datado de 5 de junho de 1974

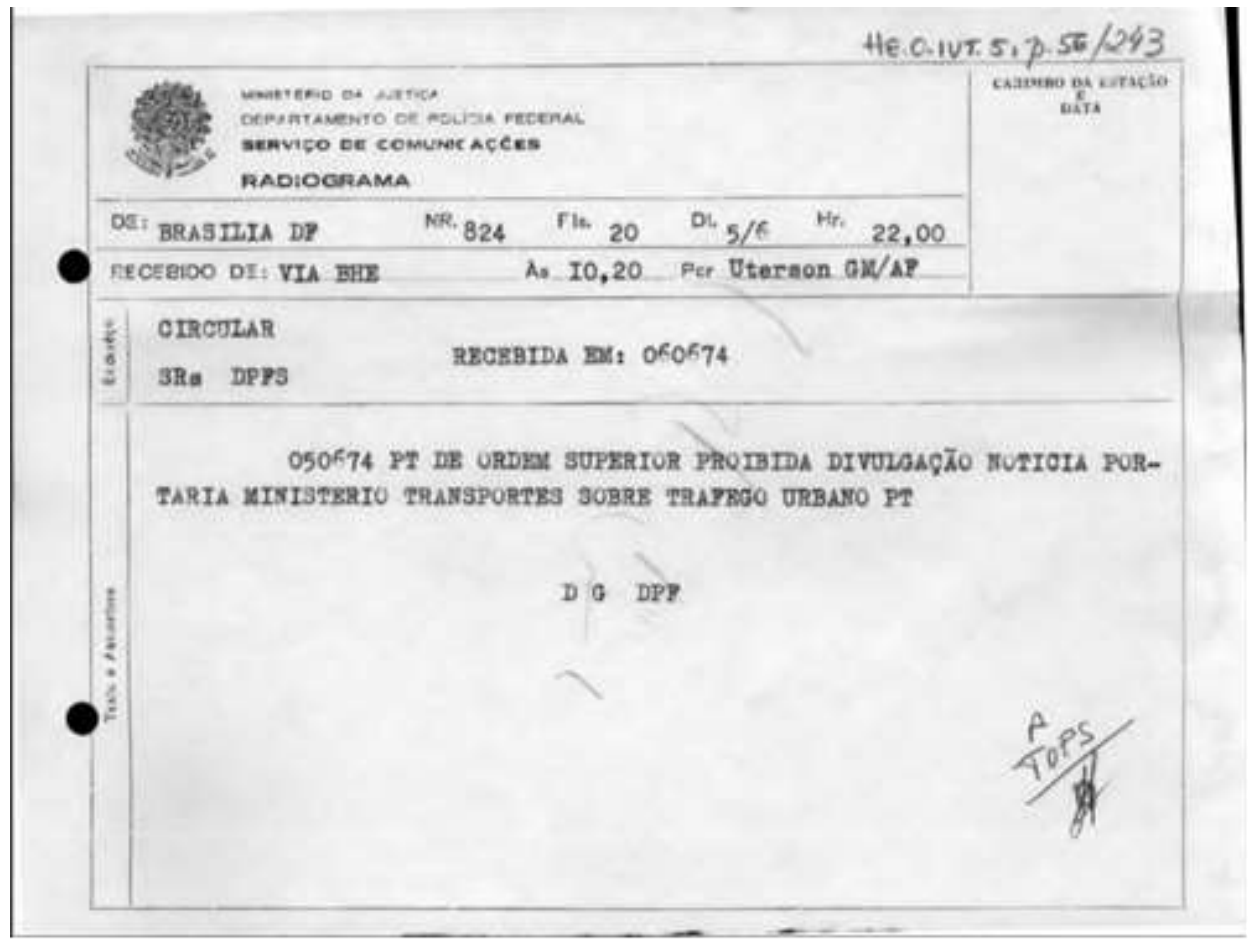

Fonte: CONSELHO DE SEGURANÇA NACIONAL. Delegacia da Polícia Federal de Juiz de Fora. Juiz de Fora: Departamento de Polícia Federal, 1974. Acervo Arquivo Nacional: pasta BR_DFANBSB_HE_O_IVT; documento BR_DFANBSB_HE_O_IVT_0005.pdf.

Figura 4 - Radiograma do Departamento de Polícia Federal para órgãos de imprensa, rádios e TVs, datado de 21 de junho de 1974

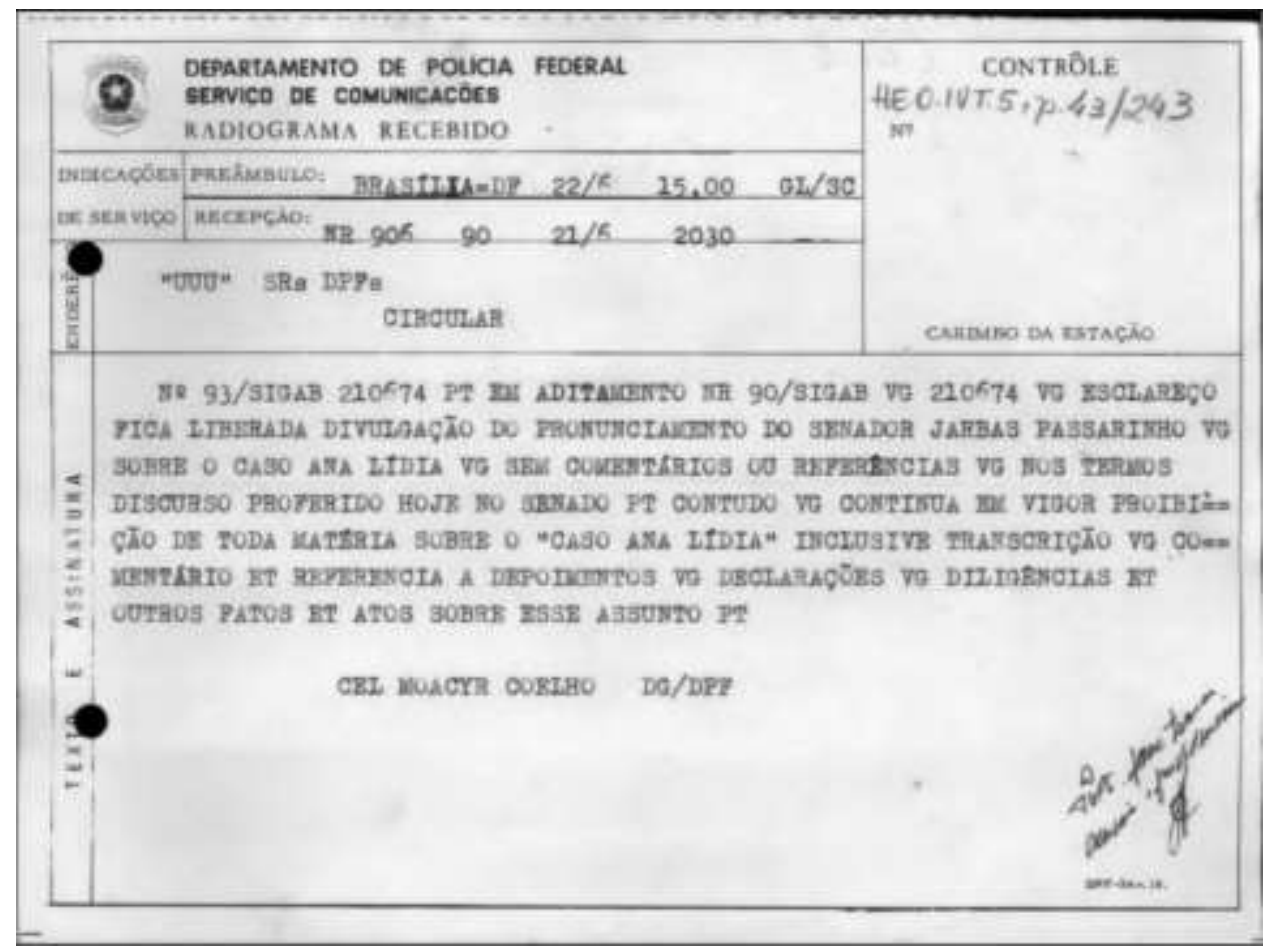

Fonte: CONSELHO DE SEGURANÇA NACIONAL. Delegacia da Polícia Federal de Juiz de Fora. Juiz de Fora: Departamento de Polícia Federal, 1974. Acervo Arquivo Nacional: pasta BR_DFANBSB_HE_O_IVT; documento BR_DFANBSB_HE_O_IVT_0005.pdf. 
Figura 5 - Radiograma do Departamento de Polícia Federal para órgãos de imprensa, rádios e TVs, datado de 28 de junho de 1974

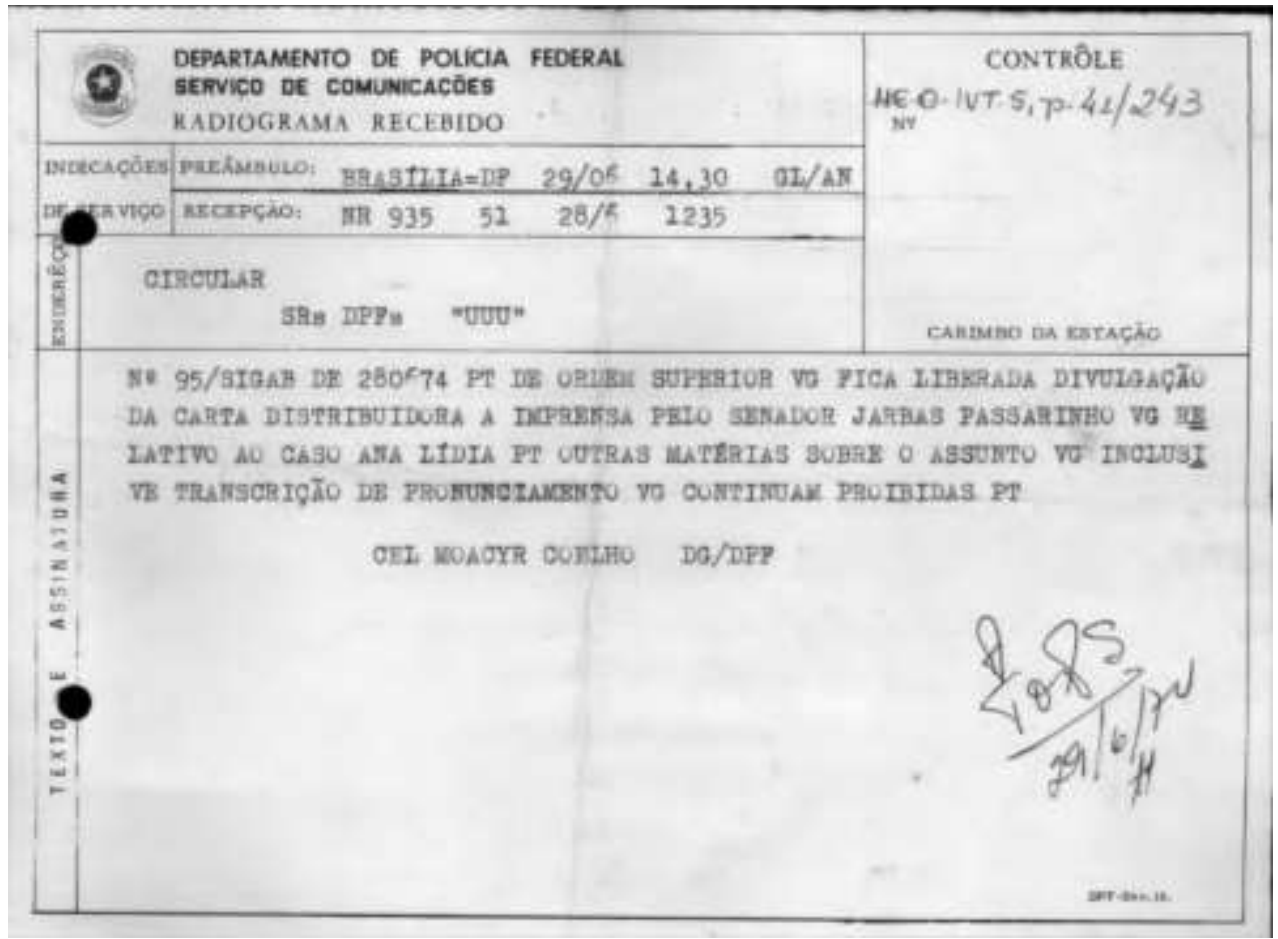

Fonte: CONSELHO DE SEGURANÇA NACIONAL. Delegacia da Polícia Federal de Juiz de Fora. Juiz de Fora: Departamento de Polícia Federal, 1974. Acervo Arquivo Nacional: pasta BR_DFANBSB_HE_O_IVT; documento BR_DFANBSB_HE_O_IVT_0005.pdf.

Figura 6 - Radiograma do Departamento de Polícia Federal para órgãos de imprensa, rádios e TVs, datado de 9 de julho de 1974

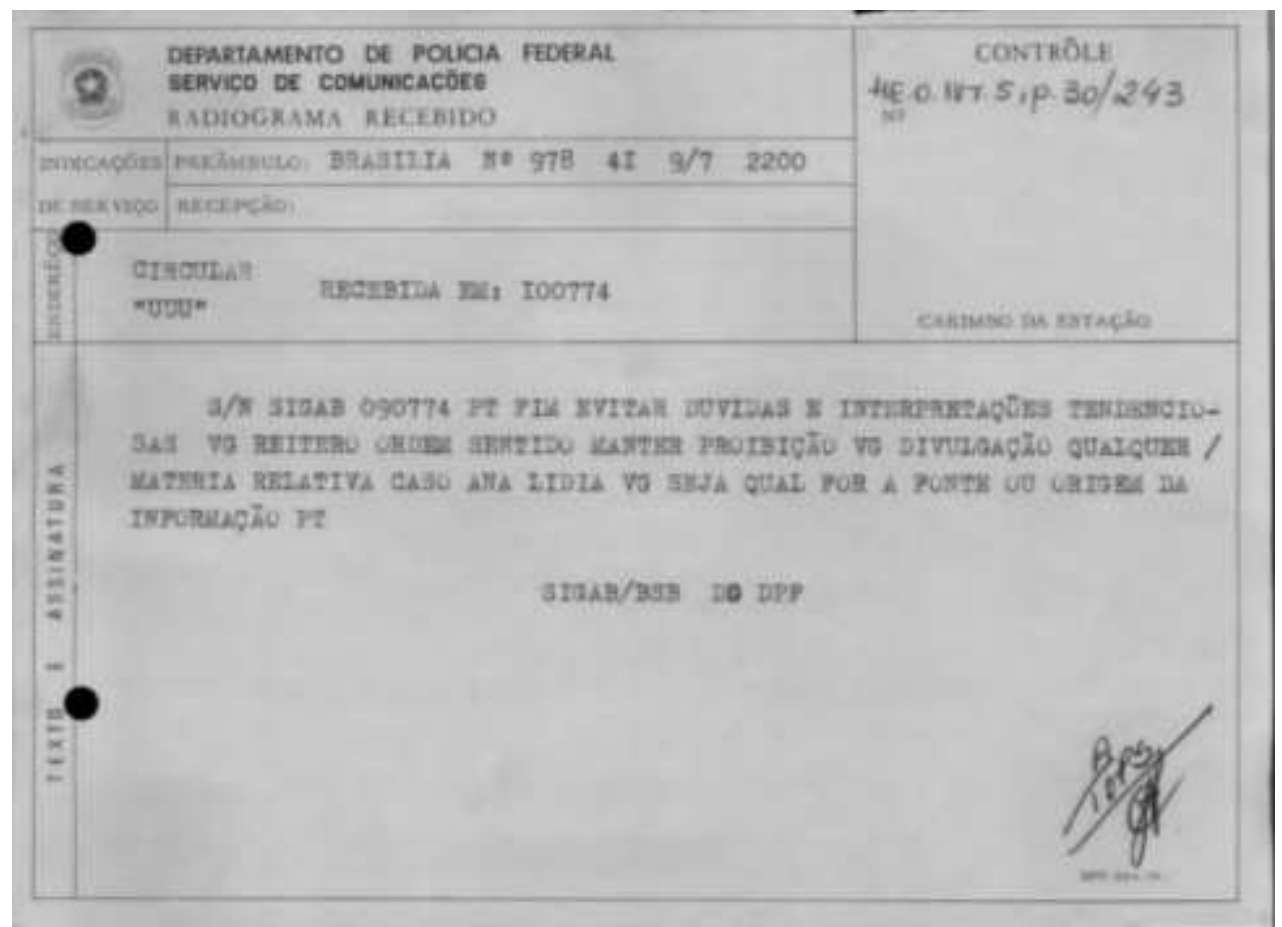

Fonte: CONSELHO DE SEGURANÇA NACIONAL. Delegacia da Polícia Federal de Juiz de Fora. Juiz de Fora: Departamento de Polícia Federal, 1974. Acervo Arquivo Nacional: pasta BR_DFANBSB_HE_O_IVT; documento BR_DFANBSB_HE_O_IVT_0005.pdf. 
Figura 7 - Radiograma do Departamento de Polícia Federal para órgãos de imprensa, rádios e TVs, datado de 30 de julho de 1974

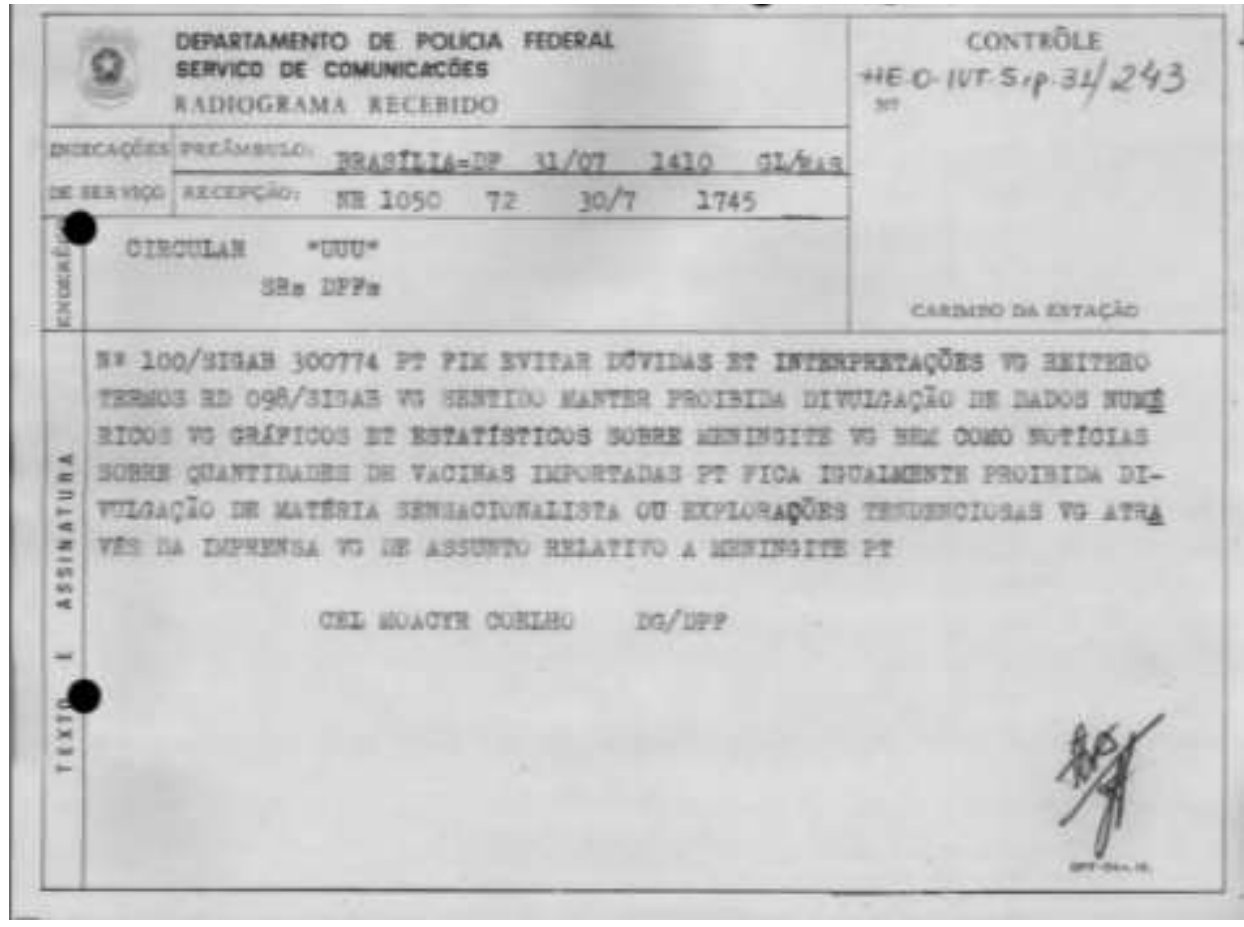

Fonte: CONSELHO DE SEGURANÇA NACIONAL. Delegacia da Polícia Federal de Juiz de Fora. Juiz de Fora: Departamento de Polícia Federal, 1974. Acervo Arquivo Nacional: pasta BR_DFANBSB_HE_O_IVT; documento BR_DFANBSB_HE_O_IVT_0005.pdf.

Figura 8 - Radiograma do Departamento de Polícia Federal para órgãos de imprensa, rádios e TVs, datado de 8 de agosto de 1974

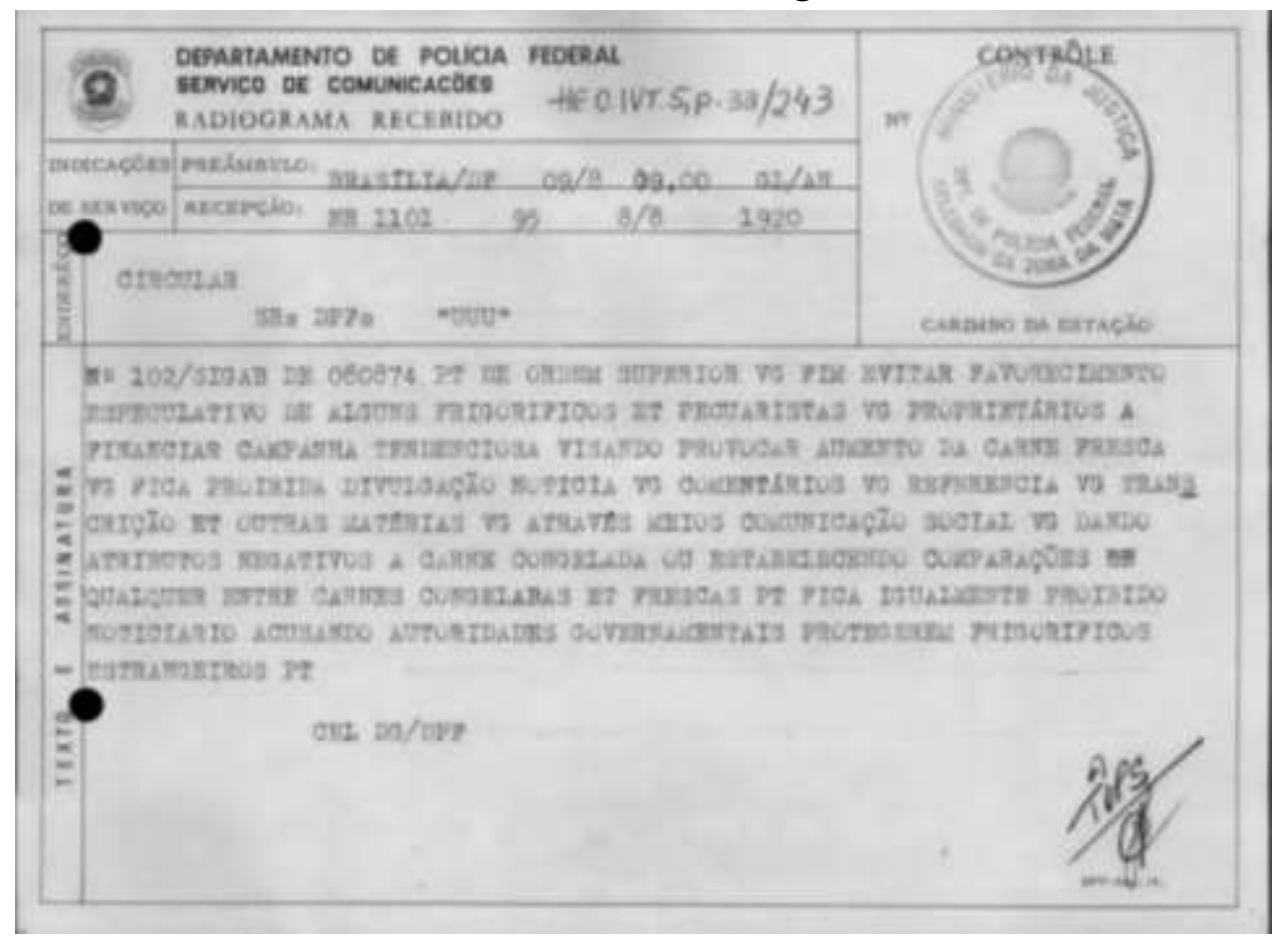

Fonte: CONSELHO DE SEGURANÇA NACIONAL. Delegacia da Polícia Federal de Juiz de Fora. Juiz de Fora: Departamento de Polícia Federal, 1974. Acervo Arquivo Nacional: pasta BR_DFANBSB_HE_O_IVT; documento BR_DFANBSB_HE_O_IVT_0005.pdf. 
Esses radiogramas (Figuras 2-8) são bons documentos para trabalhar com estudantes, pois revelam certo padrão: é possível observar o que se repete neles e também o que foge à regra; eles têm plasticidade (carimbo, parte manuscrita, parte impressa); decifrá-los é desafiador, por causa da linguagem telegráfica (os alunos e as alunas se surpreendem ao descobrirem que "VG" significa "vírgula" e "PT", "ponto"); enfim, fazem pensar. Ao mesmo tempo, como em todo documento, verificamos que há perguntas que podem ficar sem resposta, isto é, algumas coisas a fonte não me diz e, mesmo que eu procure saber, posso não chegar a uma solução - o que, aliás, é próprio de todo conhecimento, não só histórico, mas também da Física e da Medicina, por exemplo²4.

\section{Exemplos de fontes que documentam o avesso do que enunciam}

Escolher documentos para serem trabalhados nas aulas de História é trabalhoso. Nem sempre o documento que encontramos é: legível o suficiente; compreensível por si só, ou com apenas algumas explicações; atraente; não grande demais que os alunos e as alunas o repudiem; ou que não permita ser trabalhado no espaço de tempo de que dispomos. Além disso, convém ponderar até que ponto registros de violência e tortura podem ser vantajosos no trabalho com as turmas. Sempre é bom respeitar as vítimas, bem como os e as estudantes.

No fundo Divisão de Segurança e Informações (DSI), do Ministério da Justiça, depositado no Arquivo Nacional, há um conjunto de documentos intitulado "Informações do governo brasileiro para esclarecer supostas violações de direitos humanos relatadas em comunicações transmitidas pela Comissão Interamericana de direitos humanos, da Organização dos Estados Americanos" (ARQUIVO NACIONAL; EQUIPE DE DOCUMENTOS DO EXECUTIVO E LEGISLATIVO; ALVES, 2013, p. 33-34). Nesse conjunto há cópias de “cartas autênticas”, as quais, segundo a DSI (1977), "atestam o bom tratamento recebido pelos presos nas

\footnotetext{
${ }^{4}$ Pude fazer essa discussão na Jornada da Anpuh: história e ética, que teve lugar em 2014. Ver: ALBERTI, Verena. "A ética no trabalho do historiador: trabalho em mesa redonda." Jornada da Anpuh: história e ética. Rio de Janeiro, Universidade Federal do Estado do Rio de Janeiro (Unirio), 29 de outubro de $2014 . \quad$ Disponível em https://bibliotecadigital.fgv.br/dspace/handle/10438/17194. Acesso em: 30 mai. 2020.
} 
prisões, a despeito da citação de seus nomes por Ângelo Pezzuti como torturados". Uma das cartas, datada de Juiz de Fora-MG, em junho de 1970, é de um missivista chamado Erwin para a tia (Figura 9). Trata-se de um documento interessante para trabalho em sala de aula: não é muito extenso e, ao mesmo tempo, é bem plástico, pois escrito à mão em caderno pautado, o que já pode ensejar discussões sobre formas de registro disponíveis nas penitenciárias.

Figura 9 - Carta de Erwin à tia datada de junho de 1970.

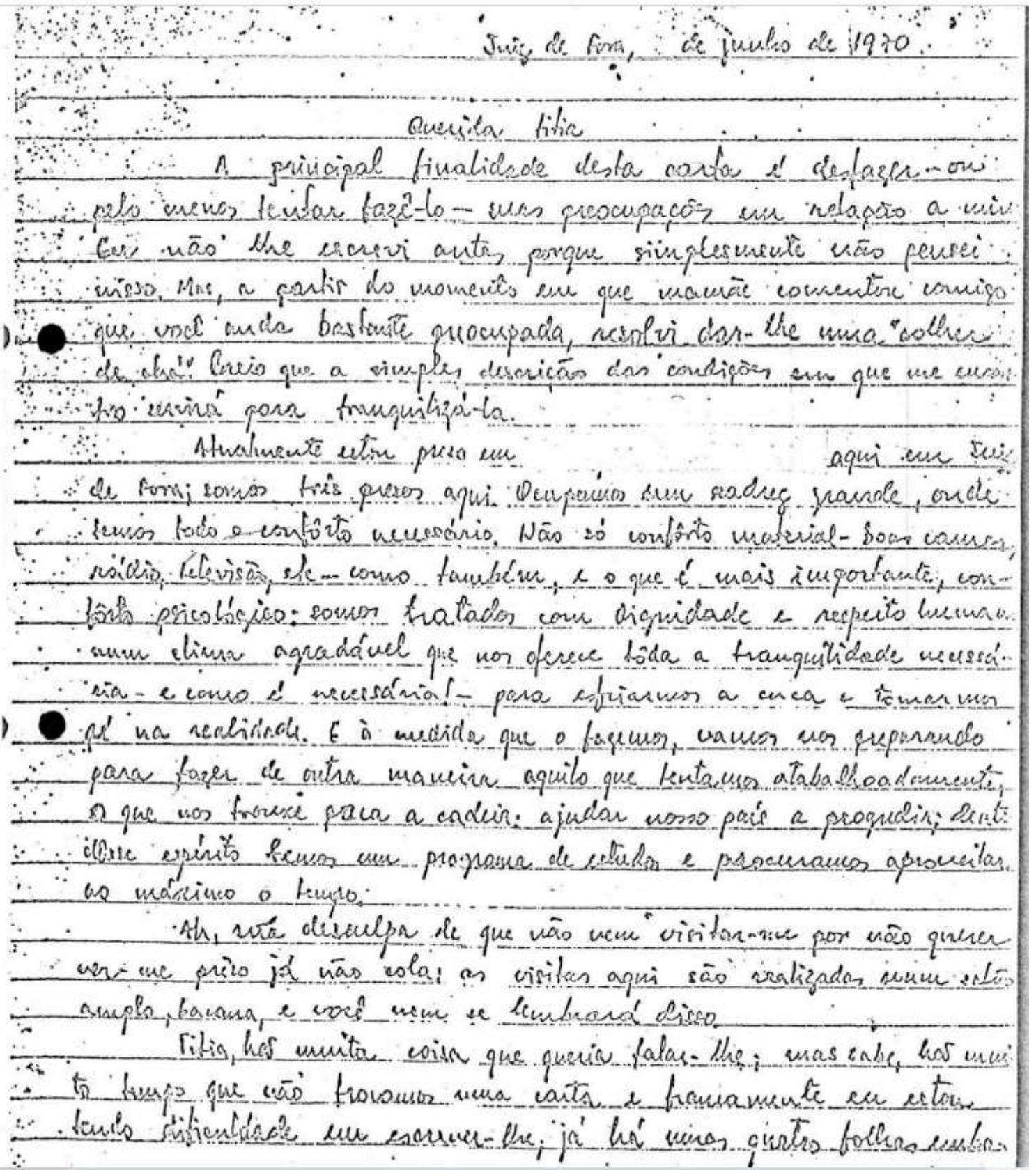




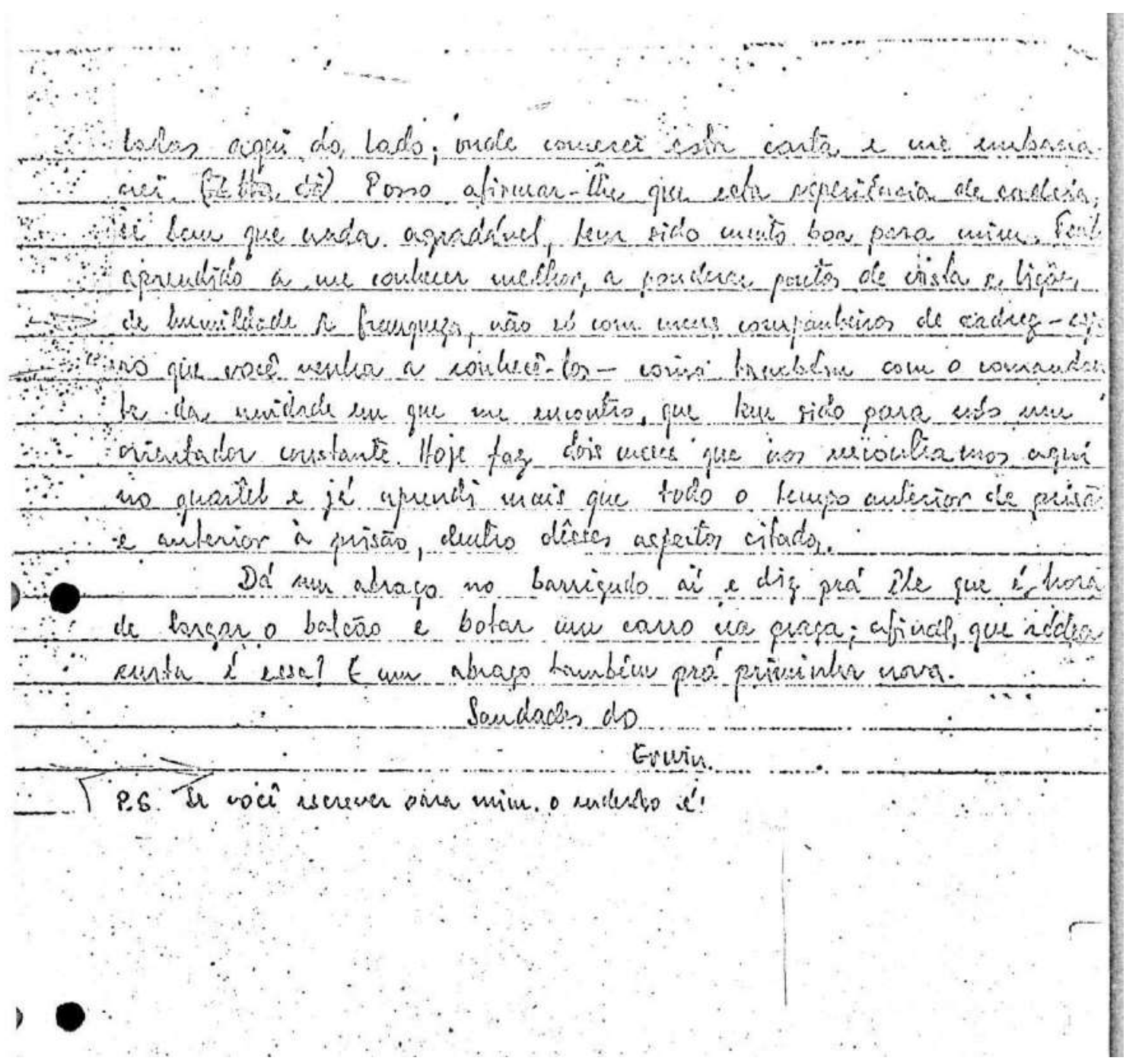

Fonte: DUARTE, Erwin Rezende. [Correspondência]. Destinatário: [Tia de Erwin]. Juiz de Fora, jun. 1970. Acervo Arquivo Nacional: Fundo Divisão de Segurança e Informações (DSI) do Ministério da Justiça. Série Movimentos Contestatórios BR.AN.RIO.TT.O.MCP.AVU.77.

Uma pesquisa no relatório da Comissão Municipal da Verdade de Juiz de Fora (JUIZ DE FORA, 2015) permitiu verificar que se trata de Erwin Rezende Duarte, preso na Penitenciária de Linhares, que, junto com outros presos como Ângelo Pezzuti, elaborou a Carta de Linhares, com o objetivo de denunciar as torturas que sofreram em diferentes unidades de forças de segurança brasileiras. $\mathrm{Na}$ carta à tia, como pode ser lido no manuscrito acima, Erwin descreve condições humanas e dignas nas quais se encontra:

Somos tratados com dignidade e respeito humano num clima agradável que nos oferece toda a tranquilidade necessária - e como é necessária! - para esfriarmos a cuca e tomar[mos] um pé na realidade. E à medida que o fazemos, vamos nos preparando 
para fazer de outra maneira aquilo que tentamos atabalhoadamente, o que nos trouxe para a cadeia: ajudar nosso país a progredir [...]. (DUARTE, 1970)

A leitura dessa e de outras cartas semelhantes permite que discutamos as muitas dimensões de documentos, uma vez que a carta documenta justamente aquilo que não está escrito, e podemos chegar a essa conclusão quando a tomamos no contexto em que foi produzida e em sua relação com outros documentos.

\section{Sintetizando}

O trabalho com documentos traz uma real possibilidade de sair da esfera da ética e dos símbolos, como apontou Federico Lorenz (2006), para trabalharmos as épocas e os processos, isto é, as situações históricas e políticas que tornaram a ditadura possível (MUCHO..., 2003). Em vez de "aprender lições", esse trabalho permite que estudemos as ações de pessoas envolvidas e afetadas pelas diferentes conjunturas políticas. Em vez da "pasteurização", ou de um conhecimento raso e rasteiro, ele traz a possibilidade de compreensão histórica.

Trata-se, como escreve Paul Salmons (2010), de abrir espaço para explorarmos a complexidade do passado e, com isso, promover um aprendizado efetivo, que ocorre quando somos obrigados a reordenar nossas categorias e entendimentos. Percebemos que esse tipo de exercício é útil não apenas na Educação Básica, mas também no Ensino Superior, seja na formação de pesquisadores e pesquisadoras de História, seja na formação inicial e continuada de professores e professoras.

Quando minha aluna perguntou “como a população reagiu ao Al-2?”, talvez ela estivesse pensando no plano da ética, procurando "tirar lições" da ditadura. Talvez ela estivesse pensando de modo semelhante às pessoas que, após "absorve[rem] [...] informações" (como escreveu Salmons na passagem já citada) sobre as atrocidades cometidas nos campos de concentração, perguntam-se como isso foi possível, como alguém pode ter feito isso (SALMONS, 2010, p. 60).

Visitar Auschwitz-Birkenau não significa que entendemos por que e como esse campo de concentração e de extermínio foi construído na Europa do século 
XX, nem como se relaciona com a história do holocausto e da Segunda Guerra (SALMONS, 2010). Ficar com um bolo no estômago após assistir ao filme $A$ Lista de Schindler tampouco garante um aprendizado efetivo, para além do acionamento de alguns valores éticos.

Federico Lorenz observa, na entrevista ao periódico Página 12 (MUCHO..., 2003), que o filme e o livro La noche de los lápices podem surtir efeito contrário ao que os professores almejam. Produzidos nos anos 1980, quando ainda era muito recente a caracterização dos jovens feita pelos militares como "subversivos" e vulneráveis à "propaganda de guerrilha", o filme e o livro apresentam os 10 estudantes secundaristas como pessoas cuja única militância política havia sido protestar contra o aumento das tarifas dos ônibus. Contudo, os jovens e as jovens faziam parte de organizações como a União dos Estudantes Secundaristas. Geralmente, os professores e as professoras buscam educar para a mobilização e para a possibilidade de mudança. Mas, diz Lorenz, quando o aluno ou a aluna assiste a um jovem de sua idade sendo torturado, no filme, pode pensar o contrário: "se, por reclamarem da tarifa, fizeram isso, bom, então é melhor não fazer nada..." (MUCHO..., 2003). Não há dúvida de que o livro e o filme devem ser vistos como documentos daquele momento de transição democrática na Argentina, e não como retratos da realidade. É assim que precisamos trabalhar com livros e filmes em sala de aula: como fontes às quais perguntamos quem, quando, por que, para quem e como foram produzidas, difundidas e preservadas.

Quando, em nossas aulas de História, enfatizamos a denúncia em vez da historicidade, não proporcionamos a nossos alunos e alunas a possibilidade de saírem do registro ético. O trabalho com documentos possibilita um efetivo estudo e aprendizado não apenas sobre a ditadura, mas também sobre as operações intelectuais envolvidas na produção do conhecimento histórico.

As "pedras de tropeço" com as quais iniciei estas reflexões certamente são um ato de denúncia. Mas elas também encerram historicidade, estão ancoradas na realidade, pois nos falam de pessoas que existiram, que tinham nome e endereço e que tiveram destinos trágicos. Não sabemos muito mais sobre elas, mas esse conhecimento lacunar também é um dado de realidade - assim como 
é um dado de realidade o fato de muitas vítimas do nazismo sequer terem endereço antes da ocupação (e, portanto, não poderem ser homenageadas dessa maneira). As pedras também são resultado de ação artística e de intervenção urbana. Nesse sentido, elas podem mostrar às crianças e aos jovens que por elas passam que é possível produzir algo a partir da reflexão e do conhecimento e que esse algo, dependendo da circunstância, também pode provocar engajamentos no futuro e possibilidades de mudança.

Ao mesmo tempo, contudo, quando nos aproximamos de suas histórias e o professor e a professora podem fazê-lo com suas turmas -, compreendemos mais uma vez as dificuldades do mundo, pois mesmo Gunter Demnig, o artista que concebeu o projeto e que criou as "pedras de tropeço", encontrou resistências em alguns lugares da Europa para instalá-las. Ou seja, mesmo as violações dos direitos humanos cometidas pelo Estado nazista não são assunto em torno do qual haja unanimidade. Isso significa que não podemos descansar 1 minuto sequer no trabalho de construção de conhecimentos sobre ditaduras.

\section{Nota Explicativa}

O Sistema de Informações do Arquivo Nacional (Sian) (https://sian.an.gov.br) disponibiliza inúmeros documentos de forma remota. Basta cadastrar-se no site e, em "Fundos/Coleções", selecionar "Pesquisa Digital". Os documentos reproduzidos neste artigo estão disponíveis respectivamente em: Fundo BR DFANBSB HE - Delegacia de Polícia Federal em Juiz de Fora (Minas Gerais), br_dfanbsb_he_0_ivt_0015_d0001de0001.pdf, p. 574; Fundo BR DFANBSB HE - Delegacia de Polícia Federal em Juiz de Fora (Minas Gerais). br_dfanbsb_he_0_ivt_0005_d0001de0001.pdf, e Fundo Divisão de Segurança e Informações do Ministério da Justiça - BR RJANRIO TT, Termo BR.AN.RIO.TT.O.MCP.AVU.77, br_rjanrio_tt_0_mcp_avu_0077_d001.pdf, p. 56-ss. 


\section{Referências}

1939: ATENTADO à bomba contra Hitler em Munique. Deutsche Welle:

Calendário histórico, [s.l.], 8 nov. 2019. Disponível em: https://www.dw.com/ptbr/1939-atentado-\%C3\%A0-bomba-contra-hitler-em-munique/a-671357.

Acesso em: 15 jul. 2020.

ALBERTI, Verena. História e memória na sala de aula e o ensino de temas controversos. In: QUADRAT, Samantha Viz; ROLLEMBERG, Denise (org.). História e memória das ditaduras do século XX. Rio de Janeiro: Editora FGV, 2015. p. 283-300.

ALBERTI, Verena. Entrelaçando saberes: educação em direitos humanos, outros espaços de saber que também educam. In: ALVES, Luís Alberto Marques (coord.). Cruzar fronteiras sobre o ensino de história: II oficinas luso-afrobrasileira. Porto: CITCEM - Centro de Investigação Transdisciplinar Cultura, Espaço e Memória, 2018. p. 113-130. Disponível em https://ler.Letras.up.pt/site/default.aspx?qry=id024id1626\&sum=sim. Acesso em: 7 ago. 2021.

ALBERTI, Verena. Fontes. In: FERREIRA, Marieta de Moraes; OLIVEIRA, Margarida Maria Dias de (coord.). Dicionário de ensino de história. Rio de Janeiro: Editora FGV, 2019. p. 107-112.

ARQUIVO NACIONAL (Brasil); EQUIPE DE DOCUMENTOS DO EXECUTIVO E LEGISLATIVO; ALVES, Marcus Vinicius Pereira. Coordenação de Documentos Escritos. Equipe de Documentos do Poder Executivo e Legislativo. Fundo: divisão de segurança e informações do ministério da justiça: inventário dos dossiês avulsos da série movimentos contestatórios. 2. ed. Rio de Janeiro: Arquivo Nacional, 2013. Disponível em:

http://arquivonacional.gov.br/images/conteudo/servicos ao cidadao/instrument os-de-pesquisa/pdf/DSI--Mov.-Cont-Avulsos-final-20-ago.pdf. Acesso em: 15 jul. 2020.

HASSELBACH, Christoph. Atentado contra Hitler completa 75 anos. Deutsche Welle, [s.l.], 20 jul. 2019. Disponível em https://www.dw.com/pt-br/atentadocontra-hitler-completa-75-anos/a-49654877. Acesso em: 15 jul. 2020.

BRASIL. Ministério da Educação. Conselho Nacional de Educação. Resolução no 1, de 30 de maio de 2012. Estabelece diretrizes nacionais para a educação em direitos humanos. Brasília: MEC, 2012. Disponível em http://portal.mec.gov.br/dmdocuments/rcp001 12.pdf. Acesso em: 14 jul. 2020.

BRASIL. Comissão Nacional da Verdade. Relatório. Brasília: CNV, 2014. Disponível em: http://cnv.memoriasreveladas.gov.br/. Acesso em: 14 jul. 2020. 
BRASIL. Ministério da Educação. Base nacional comum curricular (BNCC). Brasília: MEC, [2018]. Disponível em:

http://basenacionalcomum.mec.gov.br/images/BNCC El EF 110518 versaofinal site.pdf.. Acesso em: 15 jul. 2020.

BRASIL. Ministério da Defesa. Ordem do dia alusiva ao 31 de março de 1964. Brasília: O Ministério, 31 mar. 2019. Disponível em https://www.gov.br/defesa/ptbr/assuntos/noticias/ultimas-noticias/ordem-do-dia-alusiva-ao-31-de-marcode-1964. Acesso em: 15 jul. 2020.

BRASIL. Ministério da Defesa. Ordem do dia alusiva ao 31 de março de 1964. Brasília: O Ministério, 31 mar. 2020. Disponível em https://www.gov.br/defesa/pt-br/assuntos/noticias/ultimas-noticias/ordem-dodia-alusiva-ao-31-de-marco-de-1965. Acesso em: 15 jul. 2020.

DITADURA militar no Brasil: historiografia, política e memória. Entrevista com o historiador Rodrigo Patto Sá Motta (UFMG). Café História, [s.l.], 12 jun. 2017. Disponível em http://www.cafehistoria.com.br/entrevista-rodrigo-patto-sa/. Acesso em 1 ago. 2017.

DSI. [Cartas autênticas]. Brasília: Ministério da Justiça, [1977]. Acervo: Arquivo Nacional. Fundo Divisão de Segurança e Informações (DSI) do Ministério da Justiça. Série Movimentos Contestatórios: BR.AN.RIO.TT.O.MCP.AVU.77.

DUARTE, Erwin Rezende. [Correspondência]. Destinatário: [Tia de Erwin]. Juiz de Fora, jun. 1970. Acervo Arquivo Nacional: Fundo Divisão de Segurança e Informações (DSI) do Ministério da Justiça. Série Movimentos Contestatórios BR.AN.RIO.TT.O.MCP.AVU.77.

FREIRE, Paulo. Pedagogia da esperança: um reencontro com a pedagogia do oprimido. 17. ed. São Paulo: Paz e Terra, 2011.

GONZÁLEZ, María Paula. La última dictadura argentina en el aula: entre materiales, textos y lecturas. Revista História Hoje, São Paulo: Associação Nacional de História, v. 7, n. 13, p. 60-82, 2018. Disponível em:

https://rhhj.anpuh.org/RHHJ/article/view/426/260. Acesso em: 13 jul. 2020.

HOLLANDA, Cristina Buarque de; ISRAEL, Vinícius Pinheiro. Panorama das comissões da verdade no Brasil: uma reflexão sobre novos sentidos de legitimidade e representação democrática. Revista de Sociologia e Política, Curitiba, v. 27, n. 70, e006, 2019. Disponível em:

http://www.scielo.br/scielo.php?script=sci arttext\&pid=S010444782019000200210\&lng=en\&nrm=iso. Acesso em: 28 jan. 2020. 
JUIZ DE FORA. Comissão Municipal da Verdade. Memórias da repressão: relatório da Comissão Municipal da Verdade de Juiz de Fora. Juiz de Fora: MAMM, 2015. Disponível em http://www.juizdefora-oabmg.org.br/pdf/ebook.pdf. Acesso em: 15 jul. 2020.

LAVILLE, Christian. Que (re)viendrait faire la mémoire dans l'enseignement de l'histoire? Encounters in theory and history of education, [s.l.], v. 3, p. 5-25, Fall 2002. Disponível em: https://ojs.library.queensu.ca/index.php/encounters/article/view/1720. Acesso em: 4 ago. 2017.

LEWIS, Norman. Genocídio. Em reportagem de 1969, o extermínio sem fim dos índios do Brasil. Questões brasileiras II. Piauí, Rio de Janeiro, Edição 149, jan. 2019. Disponível em https://piaui.folha.uol.com.br/materia/genocidio/. Acesso em: 15 jul. 2020.

LORENZ, Federico Guillermo. 'Tomála vos, Dámela a mí' La Noche de los Lápices: el deber de recordar y las escuelas. In: JELIN, Elizabeth; LORENZ, Federico (comp.). Educación y memoria: la escuela elabora el passado. Madrid: Siglo XXI, 2004. Disponível em: http://abc.gov.ar/lainstitucion/programaddhhyeducacion/derechossecundario/lo renz.pdf. Acesso em: 3 ago. 2017.

LORENZ, Federico Guillermo. El pasado reciente en la Argentina: las difíciles relaciones entre transmisión, educación y memoria. In: CARRETERO, Mario; ROSA, Alberto; GONZÁLEZ, María Fernanda (comp.). Enseñanza de la historia y memoria colectiva. Buenos Aires: Paidós, 2006. p. 277-295.

MPF - Ministério Público Federal. Recomendação no 01/2019/PRDC/BA/MPF. Salvador: O Ministério, 27 mar. 2019. Disponível em: http://pfdc.pgr.mpf.mp.br/atuacao-e-conteudos-deapoio/recomendacoes/modelo-de-recomendacao. Acesso em: 15 jul. 2020.

MUCHO más allá de la historia oficial. Federico Lorenz analiza la Noche de los Lapices y como enseñar. Página 12, Martes, 16 sept. 2003. Disponível em: https://www.pagina12.com.ar/diario/elpais/1-25523-2003-09-16.html. Acesso em: 3 ago. 2017.

OLIVEIRA, Margarida Maria Dias de; FREITAS, Itamar. Base nacional curricular comum: caminhos percorridos, desafios a enfrentar. In: CAVALCANTI, Erinaldo; ARAÚJO, Raimundo Inácio Souza; CABRAL, Geovanni Gomes; OLIVEIRA, Margarida Maria Dias de. História: demandas e desafios do tempo presente: produção acadêmica, ensino de história e formação docente. São Luís: Edufma, 2018. p. 46-63. Disponível em: http://www.edufma.ufma.br/wpcontent/uploads/woocommerce uploads/2018/07/Ebook Hist\%C3\%B3riademandas-e-desafios.pdf. Acesso em: 29 dez. 2020. 
PAIVA, Maria Eliana Facciolla. Seminário Verdade e infância roubada - crianças atingidas pela ditadura. Depoimento realizado em 9/5/2013. Comissão Estadual da Verdade de São Paulo, Assembleia Legislativa do Estado de São Paulo (Alesp). 6 a 10 de maio de 2013. Disponível em:

http://comissaodaverdade.al.sp.gov.br/arquivos/videos/seminario-quotverdadee-infancia-roubadaquot-criancas-atingidas-pela-ditadura-parte-2-9-05-2013tarde. Acesso em: 15 jul. 2020.

PASTEURIZAR. In: HOUAISS, Antonio; VILLAR, Mauro de Salles. Dicionário Houaiss de língua portuguesa. Rio de Janeiro: Objetiva, 2009.

SALMONS, Paul. Universal meaning or historical understanding? The Holocaust in history and history in the curriculum. Teaching History, London: The Historical Association, n. 141, p. 57-63, Dec. 2010. Disponível em:

https://www.history.org.uk/publications/categories/300/resource/3857/teaching -history-141-the-holocaust-edition. Acesso em: 31 jul. 2017.

SÃO PAULO (Estado). Assembleia Legislativa. Comissão da Verdade do Estado de São Paulo "Rubens Paiva". Infância roubada, crianças atingidas pela ditadura militar no Brasil. São Paulo: Alesp, 2014. p. 23-25. Disponível em:

https://www.al.sp.gov.br/repositorio/bibliotecaDigital/20800 arquivo.pdf. Acesso em: 15 jul. 2020.

STM calcula que 320 pessoas estão fora da anistia. Jornal do Brasil, Rio de Janeiro. Ano 1979, Edição 00121, p. 13, 7 ago. 1979. Disponível em http://memoria.bn.br/DocReader/DocReader.aspx?bib=030015 09\&pagfis=20330 6. Acesso em: 15 jul. 2020.

VIEIRA, Oscar Vilhena; GHIRARDI, José Garcez; FEFERBAUM, Marina (coord.). Direitos humanos e vida cotidiana. Rio de Janeiro: Editora FGV, 2017. 